w6

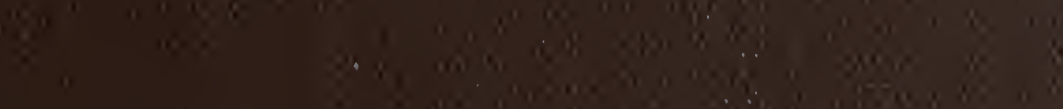
in

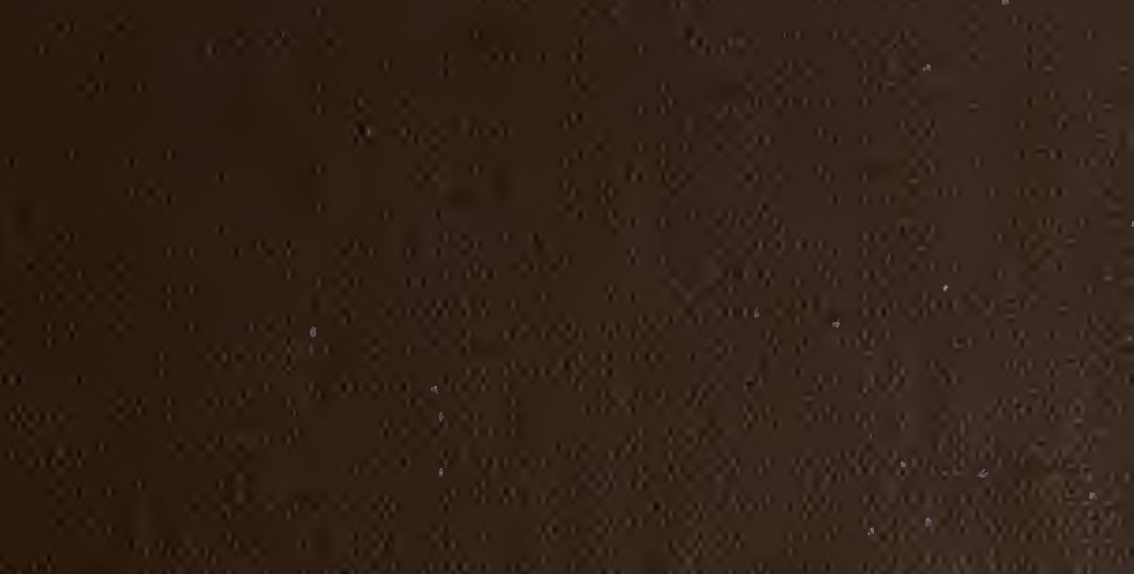




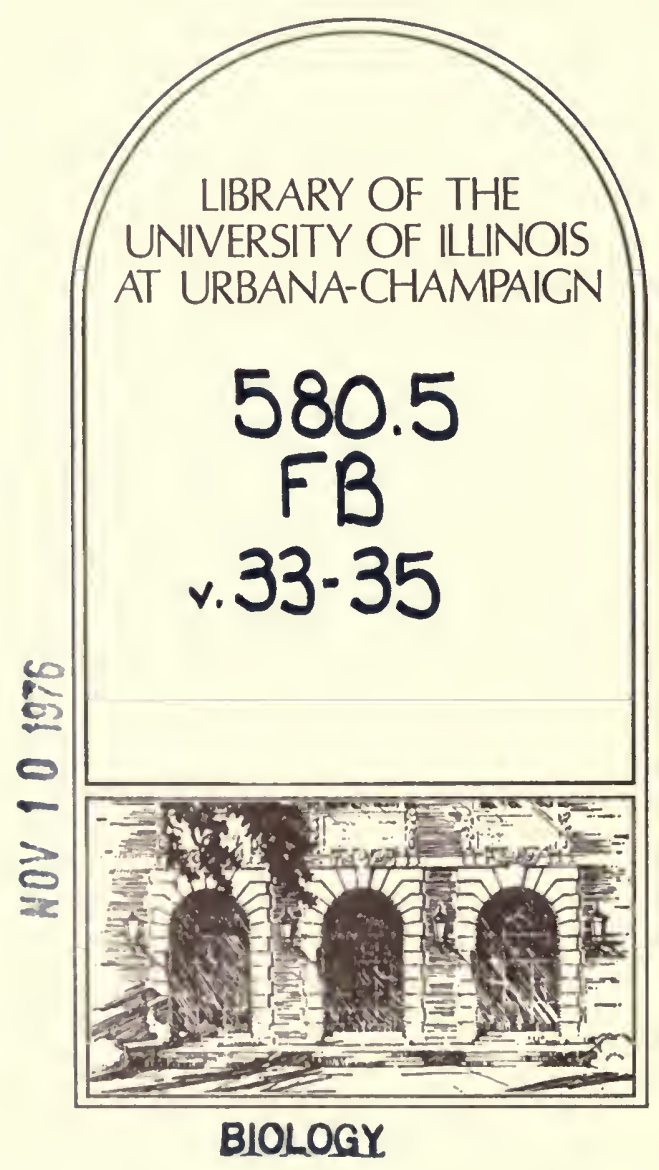


The person charging this material is responsible for its return to the library from which it was withdrawn on or before the Latest Date stamped below.

Theft, mutllation, and underlining of books are reasons for disciplinary action and may result in dismissal from the University.

To renew call Telephone Center, 333-8400

UNIVERSITY OF ILLINOIS LIBRARY AT URBANA.CHAMPAIGN

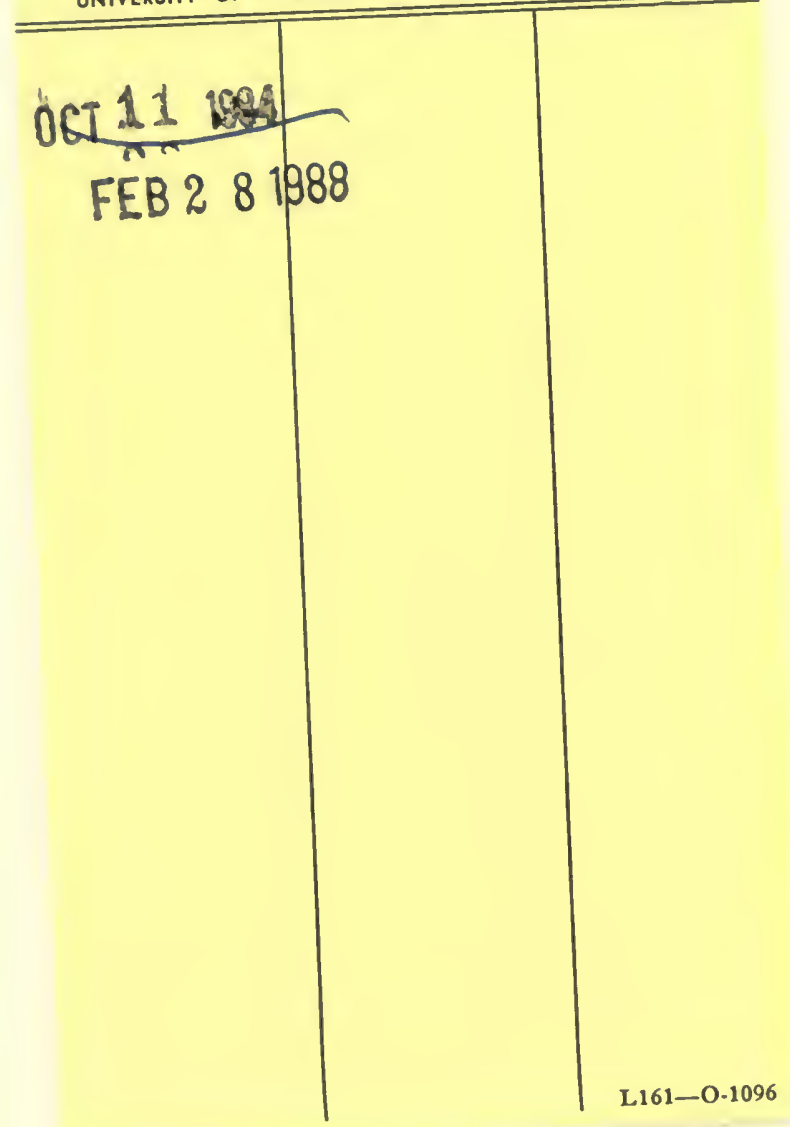







\section{FIELDIANA Botany}

\section{Studies In American Plants, III

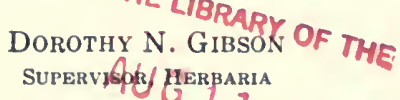

During the course of HNG Acanthaceae in the "Flora of Guatomala, Noseveral new Central American species have been distinguished antokertain new combinations were required. I wish to thank the curators of several herbaria for their kindness in lending essential specimens: The U. S. National Herbarium, the New York Botanical Garden, the Gray Herbarium of Harvard University, the University of Michigan, and the Royal Botanic Garden at Kew. Dr. W. T. Stearn, of the British Museum (Natural History) was most helpful in sharing his considerableknowledge of the family. Dr. Thomas N. Taylor, of the Department of Biological Sciences, University of Illinois at Chicago Circle, was kind enough to arrange for our use of their scanning electron microscope in order to identify and photograph pollen of certain species of Justicia and Poikilacanthus. Mr. Ron Wibel, electron microscope technician, was most cooperative. Miss Marion Pahl prepared the drawings used to illustrate this paper.

The work for this paper, and preparation of manuscript for the "Flora of Guatemala," has been carried on with assistance of grants GB-7254 and GB-27385 from the National Science Foundation to Dr. Louis O. Williams, principal investigator.

\section{APHELANDRA R. Brown}

Aphelandra schiedeana var. gigantiflora (Lindau) D. Gibson, comb. nov. A. gigantiflora Lindau, Bull. Herb. Boiss. 3: 369. 1895. A. padillana Standley, Journ. Wash. Acad. Sci. 14: 224. 1924 (type from El Salvador, Standley 19972). A. gigantiflora f. lutea Standl. \&

\section{Library of Congress Catalog Card Number: 68-26374}

Publication 1147 
Steyerm. Field Mus. Bot. 23: 237. 1947 (type from Escuintla, Guatemala, Standley 89560).

Differs flom A. schiedeana Schlecht. \& Cham. only in its elongated inflorescences (10-30 cm. long) and the more conspicuously glandular pubescence of rachis and bracts.

Guatemala: 700-1,200 m.; Escuintla; Sacatepéquez; Chimaltenango. El Salvadol; Costa Rica (?). According to Lindau's description, the plant was collected "In Guatemala et Costa Rica leg. v. Warscewicz." The label on the specimen in Berlin (F. M. Neg. 8707) reads, "Costa Rica et Veragua." However, to my knowledge, no other specimens have been seen from that area, although several collections have been made in Guatemala.

\section{CHAETOTHYLAX Nees}

\section{Chaetothylax cuspidatus D. Gibson, sp. nov.}

Herbae erectae usque $40 \mathrm{~cm}$. altae; folia lanceolata vel ovato-lanceolata, acuminata; inflorescentiae subcapitatae; bracteae oblanceolatae, cuspidatae, ciliatae, 10-15 mm. longae, bracteolae ciliatae; calyx 7-9 mm. longus; corolla 2.5-3 cm. longa; theca infera parva calcarata; pollen biporatum; capsula ignota.

Herbaceous, erect or ascending plants $30-40 \mathrm{~cm}$. tall, the stems bifariously pubescent with white hairs; leaves short-petiolate, the blades lanceolate to ovatelanceolate, acuminate, entire, 2-6 cm. long, 1-2.5 cm. wide, glabrous or with scattered pubescence mostly on costae and veins; inflorescences terminal, subcapitate, 2-4 cm. long; bracts $10-15 \mathrm{~mm}$. long, oblanceolate, cuspidate, the cusp 1 $\mathrm{mm}$. long or more, long-ciliate; bracteoles linear, gradually acuminate, rigid, 6-8 $\mathrm{mm}$. long, ciliate; calyx segments 4 , linear, subulate, 7-9 mm. long, ciliate; corolla 2.5-3 cm. long, pubescent outside, the tube 1.5-1.8 cm. long, the upper lip entire, the lower one trilobate; stamens included, the filaments attached just below the throat of the corolla, the anthers 1-1.5 mm. long, thecae superposed on a broad connective, the lower one considerably smaller, sometimes sterile, calcarate; pollen 2 -porate, bilateral; style filiform; capsule unknown.

Guatemala: Alta Verapaz, 650 m., valley of Santa Lucia, on road from Gualán to Cobán, Piltier 1792, type (F). Honduras: Dept. Olancho, trail between Catacamas and La Presa, north of Catacamas, 500-600 m., Standley 18559 and $1825 \%$.

This plant was identified by Lindau as Beloperone ramulosa Morong, a Paraguayan species which it closely resembles and which may also prove to be a Chaetothylax. However, the leaves of that plant are larger than ours, $3-10 \mathrm{~cm}$. long and to $3.5 \mathrm{~cm}$. wide, the inflorescences are axillary, the corollas a little longer, to $3.4 \mathrm{~cm}$., and the bracts apiculate or short-acuminate rather than cuspidate. 


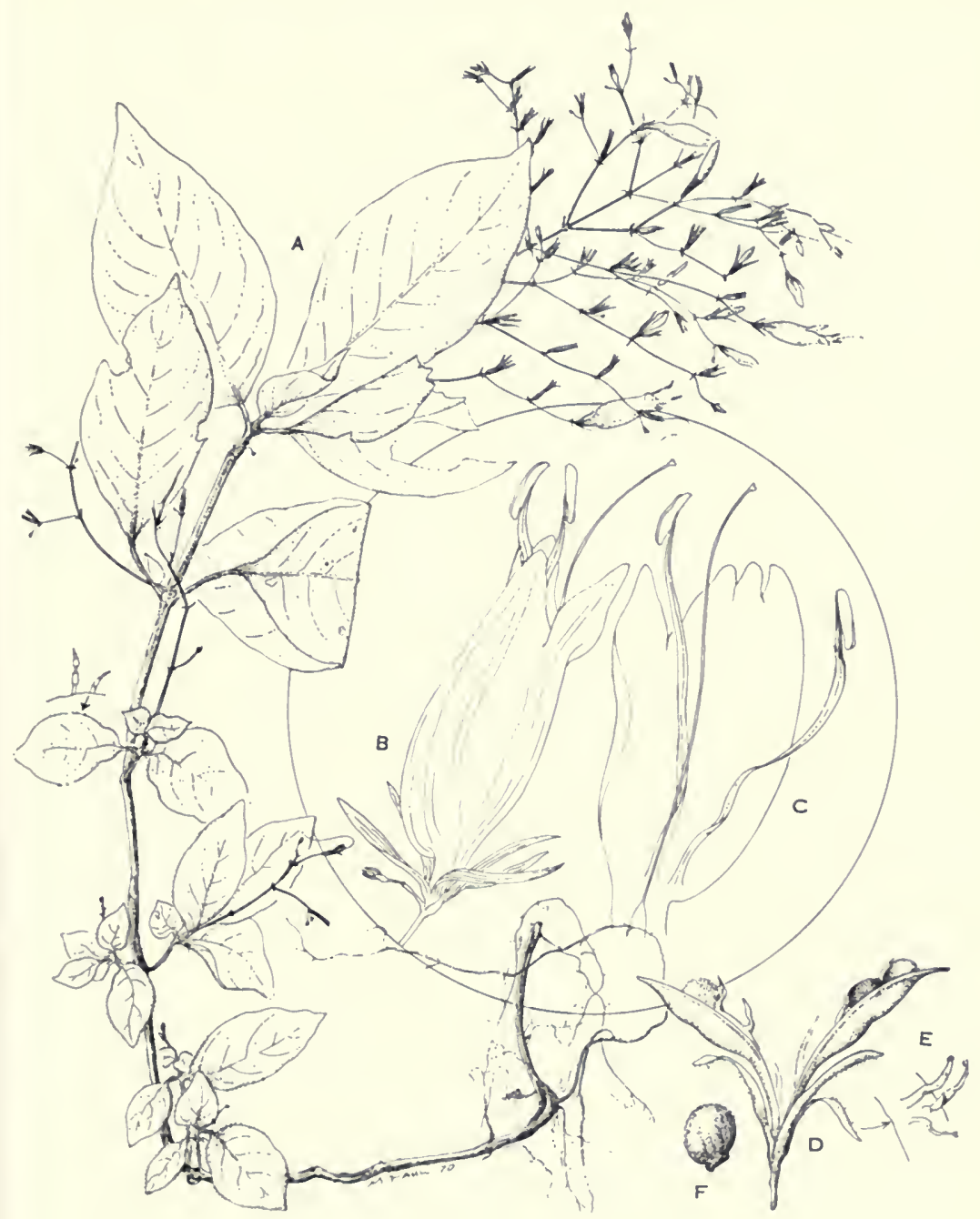

Fig. 1. Habracanthus azureus. A, habit, $\times 1 / 2 ;$ B, flower, $\times 2 \frac{1}{2}$; C, corolla opened to show stamens and pistil, $\times 21 / 2 ; \mathbf{D}$, calyx and capsule, $\times 21 / 2 ; \mathbf{E}$, hairs of calyx, greatly enlarged; $F$, seed, $\times 5$.

\section{HABRACANTHUS Nees}

Habracanthus azureus D. Gibson, sp. nov.

Herbae usque ad $2 \mathrm{~m}$; folia ovato-oblonga vel elliptica acuminata breviter pubescentia ciliolata; inflorescentiae paniculatae ramosissimae glabrae, pedicelli graciles; bracteae subulatae; calyx laciniatus, lobi lineares accrescentes $6-13 \mathrm{~mm}$. 
longi interdum glabri raro glandulari-pubescentes; corolla azurea glabra ca. $2 \mathrm{~cm}$. longa; stamina longe exserta; pollen biporatum sphaeroideum verrucosum, spinis obtusis; capsula glabra, semina 4 , verrucosa.

Herbs to $2 \mathrm{~m}$. tall, simple or branching, the stems bifariously pubescent to pilose, leaves on pubescent petioles, the blades thin, lance-oblong, ovate-oblong, or elliptic, mostly $6-12 \mathrm{~cm}$. long, $2.5-5 \mathrm{~cm}$. wide, acuminate, usually contracted at the base and more or less decurrent on the petioles, more or less pubescent on both surfaces with segmented hairs, usually more densely so on costae and veins, the margins ciliolate; inflorescences usually terminal, paniculate, $5-25 \mathrm{~cm}$. long, much branched, the rachis glabrous, the flowers borne on slender, usually glabrous pedicels; bracts subulate, 1-2 mm. long; calyx laciniate, the sepals linear, accrescent, 6-13 mm. long, usually glabrous, rarely glandular-pubescent; corolla about $2 \mathrm{~cm}$. long, blue, glabrous, the narrow portion of the tube $3-4 \mathrm{~mm}$. long, the abruptly expanded throat about $6 \mathrm{~mm}$. wide, saccate on the abaxial side, the lips subequal, the posterior lip narrowly ovate, $5-6 \mathrm{~mm}$. long, the lobes of the anterior lip 1-1.5 $\mathrm{mm}$. long; stamens long-exserted, the anthers about $3 \mathrm{~mm}$. long; pollen 2-porate, spheroidal, the sexine verrucose with blunt spines; capsule $12-15 \mathrm{~mm}$. long, glabrous, containing 4 verrucose seeds.

Guatemala: Wet mountain forest between San Rafael Pie de la Cuesta and Palo Gordo, west facing slope of the Sierre Madre Mountains, San Marcos, 1,800-2,400 m., Williams, Molina, and Williams 25808, type (F); 25595, and 26267.

Sometimes a single inflorescence will bear both glabrous and glandular-pubescent calyces. When a calyx is pubescent, the pedicel is usually more or less pubescent too.

Because of its abruptly saccate corollas with their foreshortened posterior lips, this species at first glance resembles Hansteinia rather than Habracanthus. However, unlike Hansteinia, the corollas of our plants are abruptly dilated and saccate on the abaxial side, the lips are subequal and erect as in Habracanthus; and the corollas are blue as in Habracanthus, rather than red and yellow as in Hansteinia.

\section{Habracanthus latilabris D. Gibson, sp. nov.}

Herbae suffruticosae ramosae usque ad $1 \mathrm{~m}$. Folia oblongo-ovata vel lanceolata, basi attenuata vel leviter auriculata; inflorescentia axillaris vel terminalis thyrsiformi-paniculata; calyx 4-6 m. longus, lobi lineari-acuminati; corolla alba 13-15 mm. longa, tubus 1-2 mm. diameter; stamina exserta; pollen biporatum subsphaeroideum verrucosum; capsula ignota.

Suffruticose, branching plants, about $1 \mathrm{~m}$. tall, the stems more or less pubescent; leaves short-petiolate, the blades entire, oblong-ovate or lanceolate, acuminate, rounded and abruptly attenuate to the petiole or somewhat auriculate at base, mostly $6-8 \mathrm{~cm}$. long, $2-4 \mathrm{~cm}$. wide, sparsely pubescent with scattered hairs on both surfaces, the cystoliths inconspicuous, the margins ciliate; inflorescences axillary and terminal, thyrsiform-paniculate, $7-15 \mathrm{~cm}$. long, $3-6 \mathrm{~cm}$. wide, glabrous, the branches purplish, the pedicels commonly 5-7 mm. long; bracts and bracteoles 


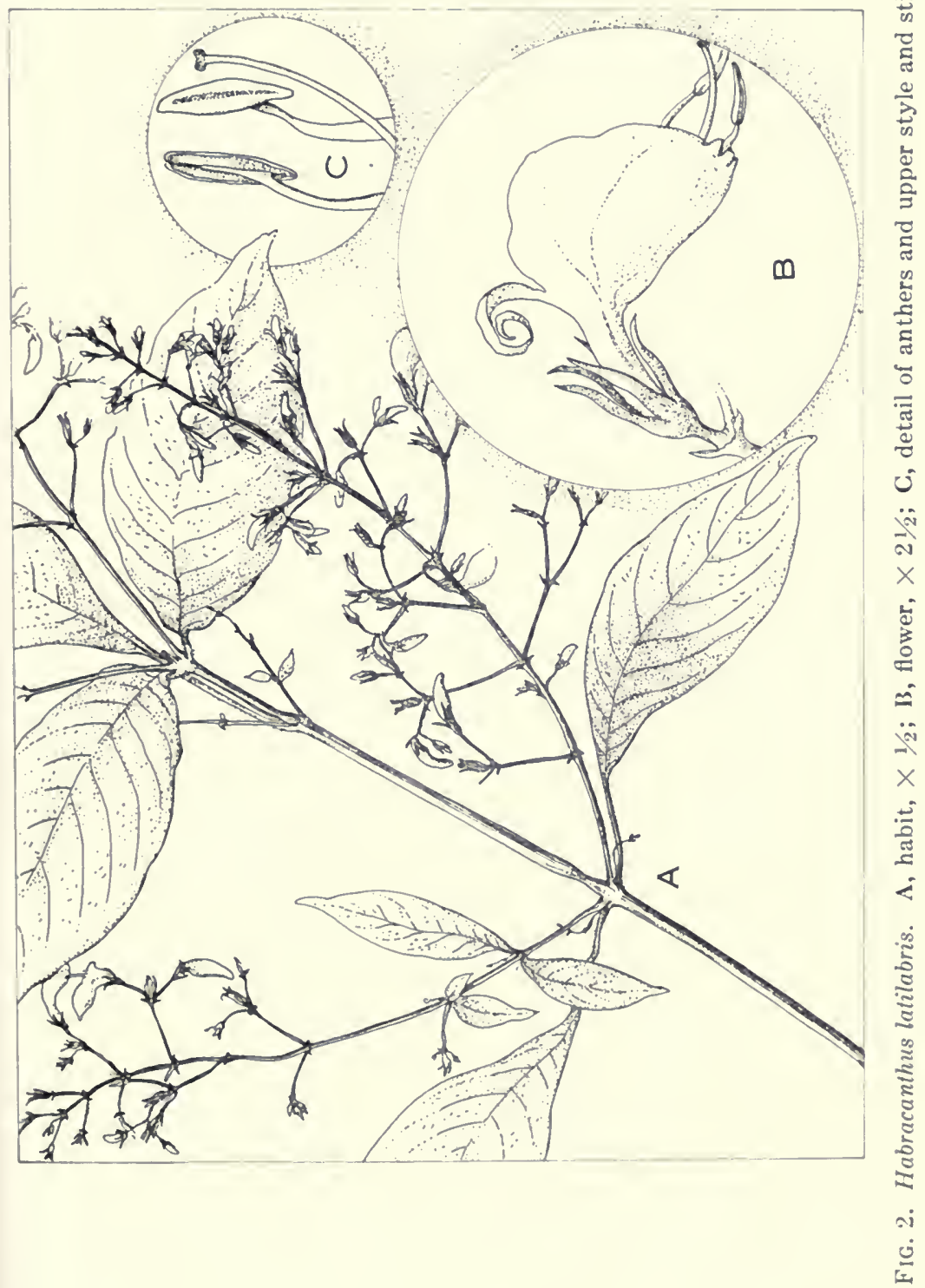


subulate, 0.5-1 mm. long; calyx 4-6 mm. long, the lobes linear-acuminate; corolla white, 13-15 mm. long, the tube 1-2 $\mathrm{mm}$. in diameter, about $4 \mathrm{~mm}$. long, the posterior lip narrowly linear, 8-9 $\mathrm{mm}$. long, the anterior one 5-7 $\mathrm{mm}$. wide, shallowly trilobate at the apex; stamens exserted, the anthers about $3 \mathrm{~mm}$. long; pollen 2-porate, bilateral, subspheroidal, verrucose with blunt spines; style filiform, exserted; capsule unknown.

Guatemala: Mixed forest, El Quiché, Cerro Putul, 1,640 m., Skutch 1836, type (US).

Differs from $H$. silvaticus Nees in its much broader anterior corolla lip, longer anthers, longer calyx, usually longer pedicels, and its pubescent leaves, rounded to auriculate at the base, with ciliate margins.

\section{Habracanthus ruberrimus D. Gibson, sp. nov.}

Herbae suffruticosae usque ad $1.5 \mathrm{~m}$. altae; folia lanceolata vel elliptica, acuminata, basi acuti vel attenuati; inflorescentia terminales, thyrsiformes aut paniculatae vulgo 5-10 cm. longae; calyx 5-lobatus, lobi angusti lineari-acuminati; corolla ruberrima, $2.5-3 \mathrm{~cm}$. longa; pollen biporatum, subsphaeroideum verrucosum; capsula ignota.

Suffruticose, branching plants to $1.5 \mathrm{~m}$. tall, the stems glabrous or bifariously pubescent; leaves short-petiolate, the blades lanceolate to elliptic, acuminate, acute or attenuate to the base, mostly $5-12 \mathrm{~cm}$. long, $1.5-5 \mathrm{~cm}$. wide, glabrous, or the younger leaves sometimes with appressed pubescence on costae and veins; inflorescences terminal, glabrous, thyrsiform to paniculate, commonly $5-10 \mathrm{~cm}$. long, $1.5-5 \mathrm{~cm}$. wide; bracts and bracteoles subulate, 1-2 mm. long; calyx lobes 5 , narrowly linear-acuminate, $3.5-5 \mathrm{~mm}$. long; corolla bright red, $2.5-3 \mathrm{~cm}$. long, the tube about $1.5 \mathrm{~mm}$. in diameter below, $2-3 \mathrm{~mm}$. above, lips $1.5-2 \mathrm{~cm}$. long, the upper one narrowly linear to oblong, the lower one $3-4 \mathrm{~mm}$. wide, shallowly trilobate at the apex; stamens exserted, anthers about $3 \mathrm{~mm}$. long; pollen 2-porate, bilateral, subspheroidal, verrucose with blunt spines; style filiform, exserted; capsule unknown.

Guatemala: Mixed forest between Chamá and Cobán, $460 \mathrm{~m}$., Alta Vera Paz, Harry Johnson 491, type (F).

Differs from other Central American species in its longer, red corollas, 2.5-3 cm. long.

\section{HANSTEINIA Oersted}

Hansteinia glabra (Leonard) D. Gibson, comb. nov. Glockeria glabra Leonard ex Lundell, Contr. Univ. Mich. Herb. 6: 60, f. 4. 1941.

Hansteinia monolopha (Donn.-Sm.) D. Gibson, comb. nov. Glockeria monolopha Donn.-Sm. Bot. Gaz. 27: 439. 1899. 


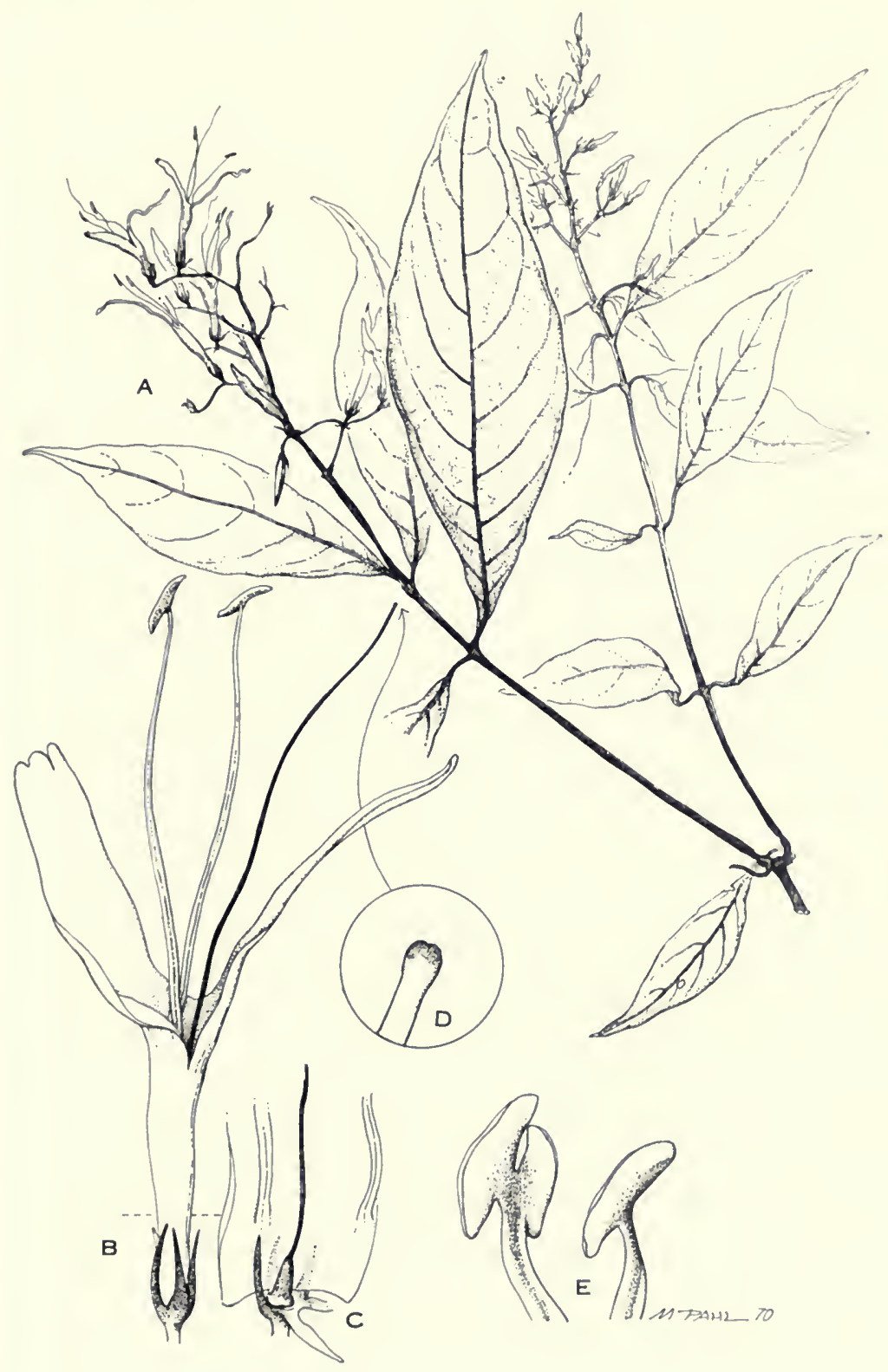

FIG. 3. Habracanthus ruberrimus. A, habit, $\times 1 / 2$; B, flower with calyx, style, and stamens, $\times 2 \frac{1}{2} ; \mathrm{C}$, corolla tube opened to show ovary and filament attachment, $\times 2 \frac{1}{2} ; \mathbf{D}$, apex of style enlarged to show stigma, $\times 5 ; \mathbf{E}$, anthers, $\times 6$. 
Hansteinia stricta (Leonard) D. Gibson, comb. nov. Glockeria stricta Leonard, Field Mus. Bot. 18: 1219. 1938.

Hansteinia ventricosa (Donn.-Sm.) D. Gibson, comb. nov. Glockeria ventricosa Donn.-Sm. Bot. Gaz. 27: 439. 1899.

\section{JUSTICIA L.}

The largest and most complex genus of the Acanthaceae, and perhaps the most difficult one, is Justicia (lectotype, J. adhatoda L.). I believe that Justicia L. (Sp. Pl. 15. 1753; Gen. Pl. 10. 1754) should include the genera Dianthera L. (Gen. Pl. 15. 1754), Beloperone Nees (in Wall. Pl. As. Rar. 3: 76. 102. 1832), Rhytiglossa Nees (in Lindl. Introd. Nat. Syst. ed. 2, 444. 1836), Jacobinia Nees (ex Moric. Pl. Nouv. Am. 156, t. 92. 1846; in DC. Prodr. 11: 331-333. 1847; Lindau in Engler \& Prantl, Pflanzenf. IV, 3b: 351. 1895), and Drejerella Lindau (in Urban, Symb. Ant. 2: 222. 1900).

Leonard (The Acanthaceae of Colombia, III, Contr. U. S. Nat. Herb. 31: 324, 488, 650. 1958) placed Beloperone in synonomy under Justicia but maintained Jacobinia as a separate genus, on the basis that the thecae of Jacobinia are muticous and "slightly" superposed while those of Justicia are appendaged and superposed. However, the thecae of the type specimen of Jacobinia, J. lepida Nees ex Moric., are conspicuously appendaged. The original description of Jacobinia reads in part, “. . . antherae bilocellatae oblongae, basi profunde sagittatae, locellis in connectivo angusto parallellis utroque basi calcarato altero paulo demissiore."

Grant (A cytogenetic study in the Acanthaceae, Brittonia 8: 121149. 1955) found many species of both Justicia and Jacobinia to have a 2 n chromosome number of 28 . The pollen studies of Raj (Pollen morphological studies in the Acanthaceae, Grana Palynol. 3(1): 3-108. 1961) and Petriella (El Polen de las Acanthaceae Argentinas, Rev. Mus. La Plata 11, Bot. 53: 51-68. 1968) pointed out the extremely close affinity between the two genera.

Raj concluded that "The Justicieae, as far as investigated, seem to form a homogenous group. All have porate pollen grains (in some species there is a faint indication of a colpus) and the sexine pattern is more or less the same." Petriella stated more specifically that “. . Justicia y Jacobinia no se pueden separar por los carácteres polínicos (aunque puede habérselo fácilmente con carácteres morfológicos externos). Podría decirse que Jacobinia presenta en general 
ínsulas más pequeñas y con un retículo más simple, pero esto no es en modo alguno absoluto, ya que existen en ambos géneros granos de polen con caracteristicas similares." He does not explain nor justify his statement concerning external morphological characters, but it seems reasonable that it is based on the assumption that other authors were correct in their assessment of the importance of the character of the thecae. The observations of Raj and Petriella are borne out by my own examination of pollen grains of both groups. I have also found so much variation in thecae placement and appendages, as well as width of the connective, that I am convinced it is no longer practicable to maintain Jacobinia as a separate genus.

The pollen of Drejerella, like that of Justicia comata (L.) Lam., $J$. campechiana Standley, and J. grandifolia D. Gibson (fig. 8A) is 3-porate, and prolate to subprolate, trigonous, presenting quite a different aspect from the 2-porate, bilateral, often ellipsoidal pollen grains of the typical Justicia-Jacobinia complex (fig. 8B). However, the trema area of these exceptions is marked by lines of insulae surrounding the apertures, as in Justicia, and it would be most difficult to separate the two groups on morphological characters. Bremekamp (Delimitation and Subdivision of the Acanthaceae, Bull. Bot. Surv. India 7: 29. 1965) concluded that the character of the pore situation between rows of insulae is "apparently of greater taxonomic value than the number of pores." Dr. W. T. Stearn, of the British Museum, informs me that as a result of his palynological and other work, he has decided to incorporate Drejerella in Justicia in the Flora of Jamaica, and it seems expedient to follow this reasoning in the "Flora of Guatemala."

Deviating more strongly are the 4-porate pollen grains of $J$. ensiflora (Standley) D. Gibson (fig. 9), J. montana (Standley \& Leonard) D. Gibson (fig. 10A), J. multicaulis Donn.-Sm., and $J$. silvicola D. Gibson (fig. 10B). Pollen grains of all of these species do have the characteristic rows of insulae in the trema area, but in $J$. ensiflora some of the insulae are apparently fused and the membrane covering the aperture is verrucose. Although the position of these species may be uncertain, it seems best to hold them in Justicia for the present.

In addition to the following several new species, varieties, combinations, and names in the genus, a discussion of the variable and confusing Justicia breviflora (Nees) Rusby is appropriate here and is therefore included. 
Justicia angustiflora D. Gibson, nom. nov. Beloperonoides macrantha Oerst. Vid. Medd. 162. 1854. Beloperone macrantha Benth. \& Hook. Gen. Pl. 2: 1111. 1876, non Justicia macrantha Benth. Pl. Hartweg. 78. 1841.

Justicia aurea f. erythrantha (Standl. \& Steyerm.) D. Gibson, comb. nov. Jacobinia umbrosa f. erythrantha Standl. \& Steyerm. Field Mus. Bot. 23: 241. 1947.

Justicia bartlettii (Leonard) D. Gibson, comb. nov. Beloperone bartlettii Leonard, Carnegie Inst. Wash. Publ. 461: 232, f. 18. 1936.

Justicia brenesii (Leonard) D. Gibson, comb. nov. Beloperone brenesii Leonard, Field Mus. Bot. 18: 1201-1202. 1938.

Justicia breviflora (Nees) Rusby, Bull. Torr. Bot. Club 27: 78. 1900. Rhytiglossa breviflora Nees in DC. Prodr. 11: 352.1847 (type, Linden 184, Mexico). R. ovatifolia Oersted, Vid. Medd. Kjoebenhavn 156. 1855. Dianthera breviflora Hemsl. Biol. Cent. Am. Bot. 2: 517. 1882. D. peckii Blake, Contr. Gray Herb. 52: 97.1917 (type from British Honduras, Peck 722). D. riparia Blake, Contr. U. S. Nat. Herb. 24: 25. 1922 (type from Izabal, Guatemala, Blake 7800). Justicia peckii Standley, Field Mus. Bot. 12: 369. 1936.

Neither Leonard nor Standley was consistent in placing material in $J$. breviflora or in the species which they sometimes segregated. Leonard had under study a plant on which he had put an as yet unpublished name, but at that time he also had available to him in his herbarium identical specimens which he had determined as $J$. breviflora and which closely resemble the description and the typephotograph (F.M. Neg. 22192) of Rhytiglossa ovatifolia Oersted.

According to Nees' original description, the corollas of $J$. breviflora are relatively short, $10-11 \mathrm{~mm}$. (5 lines) long, and the leaves have 8-9 pairs of lateral veins. Corollas pictured in the photograph of the type specimen, Linden 184 (F.M. Neg. 26570), measure 15-16 mm. long; the leaves do have nine pairs of veins. All but one of the specimens examined with the right number ( 8 to 10 pairs) of lateral veins, have corollas $18-23 \mathrm{~mm}$. long, usually sparsely pubescent. The exception is Goll 257, with glabrous corollas 14-15 mm. long on one inflorescence and $18 \mathrm{~mm}$. long on another. Guatemalan plants with glabrous corollas 10-16 mm. long, J. peckii, match most closely the original description and the type-photograph of $J$. breviflora except that they have leaves with only 5-7 pairs of lateral veins. Pollen from plants of both extremes looks much the same. 
Plants in this complex are quite variable in leaf shape and size and in length of calyces and corollas. If one had only the extremes, it would be relatively easy to separate those specimens with corollas 18-23 mm. long and broad leaves acute or attenuate to the base, from those with corollas $10-15 \mathrm{~mm}$. long and narrow leaves rounded at the base. With almost complete intergradation between the two extremes, it seems best to place them under a single specific name.

Justicia californica (Benth.) D. Gibson, comb. nov. Beloperone californica Benth. Bot. Voy. Sulph. 38. 1844.

Justicia californica var. conferta (Brandg.) D. Gibson, comb. nov. Beloperone californica var. conferta Brandg. Proc. Cal. Acad. ser. 2: 194. 1889.

Justicia chamaephyton D. Gibson, nom. nov. Beloperone variegata Lindau in Pittier, Anal. Inst. Fis.-Geog. Costa Rica 9: 188. 1898; Prim. Fl. Costaricensis 2: 315. 1900, non Justicia variegata Aubl. Pl. Guiana 1: 12, t. 4. 1775.

Leonard (in Standley, Flora of Costa Rica, Field Mus. Bot. 18: 1203. 1938) placed Streblacanthus chirripensis Lindau in synonomy with $B$. variegata. However, the leaf bases of the former are described as "sensim angustata" and the flowers as "lilacini," while the leaf bases of our plant are rounded, and the corollas yellow.

\section{Justicia corynimorpha D. Gibson, sp. nov.}

Herbae erectae vel decumbentes usque ad $60 \mathrm{~cm}$. altae; folia anguste oblonga, lanceolato-oblonga vel elliptica, acuminata, basi attenuata, glabra; inflorescentiae terminales vel axillares, spicatae vel subcapitatae; bracteae clavatae vel spatulatae; calyx quinquilobatus, $5-8 \mathrm{~mm}$. longus; corolla lavandula, $2-2.5 \mathrm{~cm}$. longa; theca infera leviter calcarata; pollen biporatum; capsula puberula, 1-1.5 cm. longa.

Erect or decumbent, sparsely branched herbs to $60 \mathrm{~cm}$. tall, the stems glabrous; leaves short-petiolate, the blades narrowly oblong, lanceolate-oblong or elliptic, mostly 4-12 cm. long, $1-2.5 \mathrm{~cm}$. wide (rarely linear and only $0.3 \mathrm{~mm}$. wide), acuminate, attenuate to the base, glabrous, the cystoliths conspicuous; inflorescences terminal or axillary, spicate or subcapitate; bracts clavate to spathulate, 7-13 mm. long, short-pubescent or glabrate, sometimes glandular, rarely ciliolate; bracteoles similar but smaller; calyx segments 5, narrowly linear-lanceolate, acuminate, $5-8 \mathrm{~mm}$. long, usually glabrous, sometimes ciliolate; corolla lavender or purple, $2-2.5 \mathrm{~cm}$. long, somewhat pubescent or glabrate outside, the tube more or less ampliate; stamens about equalling the lips of the corolla, the thecae about $2 \mathrm{~mm}$. long, one below the other on the connective, at least the lower one minutely calcarate; pollen 2-porate, bilateral (fig. 7A); capsule puberulent, 1-1.5 cm. long, the seeds subglobose, minutely puberulent. 
Guatemala: Jutiapa, between Jutiapa and La Burrera, 800-850 m., Standley 75969, type (F); Chiquimula, llanos around Ipala, alt. 900 m., Steyermark 30317; Escuintla, Aguilar 1687, 1700; Retalhuleu, alt. 240 m., Standley 88764; Santa Rosa, about 325 m., Standley 79701; Suchitepéquez, Cocales, alt. 215 m., Standley 62101; Zacapa, in plaza at Teculután, 250-275 m., Steyermark 42104. Mexico: Paderon, Tonala, Chiapas, Matuda 16931; Honduras: in shrub forest near San Lorenzo, Depto. Valle, alt. $30 \mathrm{~m}$., Williams \& Molina 10783; Nicaragua: Depto. Zelaya, Molina 2240, $2348,2432$.

Differs from $J$. carthagenensis Jacq. in its narrow leaves, clavate bracts, shorter calyces and corollas, and shorter capsules. Pollen grains of $J$. carthagenensis and $J$. corynimorpha are very similar, but the insulae surrounding the apertures in the trema areas of $J$. corynimorpha are fewer and a little more widely spaced.

\section{Justicia eburnea D. Gibson, sp. nov.}

Frutex 2-6 m.; folia oblongo-elliptica vel oblongo-ovata, acuminata, basi cuneata; inflorescentiae paniculatae spici pauciflorae; bracteae subulatae, minutae; lobi calyces 4 , glabri, 3-4 $\mathrm{mm}$. longi; corolla eburnea, $3 \mathrm{~cm}$. longa; thecae antherarum $2 \mathrm{~mm}$. longae, calcaratae; pollen biporatum; capsula glabra, $1 \mathrm{~cm}$. longa.

Shrubs 2-6 m. tall, glabrous throughout; leaves on petioles $0.3-2.5 \mathrm{~cm}$. long, the blades oblong-elliptic to oblong-ovate, acuminate, acute to cuneate at the base, mostly 6-16 cm. long, 2-7 cm. wide, of ten blackening when dry; inflorescences short, terminal or axillary panicles composed of few-flowered spikes; bracts subulate, minute; calyx segments 4 , narrowly lanceolate, acuminate, $3-4 \mathrm{~mm}$. long, glabrous; corolla creamy-white, sometimes greenish near base of tube, about $3 \mathrm{~cm}$. long, the lips nearly half as long as the tube, the posterior one entire, the anterior trilobate, the tube about $3 \mathrm{~mm}$. wide; stamens about as long as the corolla, anthers about $2 \mathrm{~mm}$. long, one theca only slightly lower than the other on the connective, calcarate; pollen 2-porate, isopolar, bilateral (fig. 7B); capsule about $1 \mathrm{~cm}$. long, glabrous, containing 4 compressed, suborbicular, verrucose seeds.

Guatemala: Izabal, Río Dulce, 1-3 m., 2-4 miles west of Livingston, Steyermark 39535, type (F); Alta Verapaz, 6-8 miles northwest of Cubilgüitz, 210-250 m., Steyermark 45023; Petén, Cerro Ceibal, between mouth of Río Santa Mónica and mouth of Río San Martín, on left side of Río Cancuen, 75-150 m., Steyermark 46109.

These plants have been confused with $J$. bartlettii (Leonard) D. Gibson, which has bracts 5-6 mm. long, pilosulous calyces 7-12 mm. long, pale yellow to buff corollas, the tubes $4-5 \mathrm{~mm}$. wide, and thecae conspicuously superposed, one considerably lower than the other on the connective. 
Justicia effusa D. Gibson, nom. nov. Beloperone steyermarkii Leonard, Fieldiana: Botany 28: 555. 1953. Justicia steyermarkii Leonard, Contr. U. S. Herb. 31: 523. 1958, non Justicia steyermarkii Standley \& Leonard, Field Mus. Bot. 23: 243, f. 4. 1947.

Justicia ensiflora (Standley) D. Gibson, comb. nov. Jacobinia ensiflora Standley, Field Mus. Bot. 8: 45. 1930.

The surface of the 4-porate pollen grains is marked by rows of large, densely arranged insulae (fig. 9A) and the membrane covering the apertures is conspicuously verrucose (fig. 9B).

Justicia flava D. Gibson, nom. nov. Beloperone aurea Leonard, Carn. Inst. Wash. Publ. 461: 233, f. 19. 1936, non Justicia aurea (Rose) Lindau, Bull. Herb. Boiss. 5: 675. 1897.

Justicia graciliflora (Standley) D. Gibson, comb. nov. Beloperone graciliflora Standley, Contr. Arn. Arb. 5: 142, t. 20. 1933.

\section{Justicia grandifolia D. Gibson, sp. nov.}

Frutex usque ad $1.75 \mathrm{~m}$; folia elliptica vel lanceolato-oblonga, acuminata, glabra, basi attenuata, 20-35 cm. longa; inflorescentia terminalis, pedunculata, spicata, anguste thyrsiformis; bracteae lineari-oblongae vel ellipticae; lobi calyces 5 , lineares vel lineari-lanceolati, acuminati, $10-12 \mathrm{~mm}$. longi, ciliati; corolla flava, plus minusve $5 \mathrm{~cm}$. longa; thecae antherarum $3 \mathrm{~mm}$. longae, calcaratae; capsula ignota.

Suffruticose plants to $1.75 \mathrm{~m}$. tall, the stems bifariously pubescent or almost wholly glabrous; leaves subsessile or on petioles only $0.5 \mathrm{~cm}$. long, the blades elliptic to lance-oblong, short-acuminate, attenuate to the base, $20-35 \mathrm{~cm}$. long, 7-9 $\mathrm{cm}$. wide, glabrous on both surfaces, the margins entire, the cystoliths small but numerous and conspicuous; inflorescences terminal, pedunculate, spicate, appearing narrowly thyrsiform, 24-28 cm. long; bracts linear-oblong to elliptic, obtuse, 12-13 mm. long, minutely puberulent or glabrate, ciliate; bracteoles similar but smaller; calyx segments 5, linear to linear-lanceolate, acuminate, 10-12 mm. long, ciliate; corolla pale yellow, about $5 \mathrm{~cm}$. long, bilabiate, the lips tinged with green, the upper one minutely bifid, the lower one minutely trilobate; stamens about equalling the corolla, the anthers about $3 \mathrm{~mm}$. long, calcarate, one theca below the other on the connective; pollen trigonous, 3-porate, with one row of insulae on either side of each aperture (fig. 8A); capsule unknown.

Guatemala: Izabal, damp, forested slopes, 300-900 m., Steyermark 42001, type $(\mathrm{F})$.

This plant has been confused with $J$. magniflora (Leonard) D. Gibson, which has leaves on petioles $1-3 \mathrm{~cm}$. long, the blades with crenulate margins, bracts only $7-8 \mathrm{~mm}$. long, and calyx lobes only 5-6 mm. long. 


\section{Justicia macrantha var. piliformis D. Gibson, var. nov.}

Frutices, rami pilosi aut glabrati; folia ovata vel lanceolata, acuminata, supra sparse pilosa vel glabrata, infra dense pilosa, glabrescentes, vulgo ciliata; inflorescentiae cymosae, subsessiles aut pedunculatae, pedunculi, pedicelli pilosi; bracteae pubescentes, ciliatae; corolla rubra, $5-5.5 \mathrm{~cm}$. longa; stamina corolla subaequilonga; thecae reniformes.

Branching shrubs, 3-4 m. tall, the stems and branches pilose or the branches glabrate in age; leaves on petioles $0.5-1.5 \mathrm{~cm}$. long, the blades thin, ovate to lanceolate, acuminate at the apex, of ten abruptly so, rounded at base and abruptly decurrent on the petiole, mostly $5-13 \mathrm{~cm}$. long, $3-6 \mathrm{~cm}$. wide, sparsely pilose or glabrate above, densely pilose beneath when young, usually sparsely so in age, the margins of ten conspicuously ciliate; inflorescences axillary and terminal, cymose, subsessile or on peduncles to $0.5 \mathrm{~cm}$. long, the peduncles and pedicels densely pilose; bracts and bracteoles triangular to lanceolate, acute, $2-4 \mathrm{~mm}$. long, pubescent, ciliate; corollas red, $5-5.5 \mathrm{~cm}$. long, the tube glabrous outside, the lips pubescent outside on the upper portions, $2-2.5 \mathrm{~cm}$. long, the posterior lip bidentate, the anterior lip trilobate, spreading, about $0.8 \mathrm{~cm}$. wide; stamens equalling or slightly longer than the posterior lip, the thecae curved, converging at the tips but diverging at the base, the connective $1.5-2 \mathrm{~mm}$. wide; capsule unknown.

Guatemala: Mixed forest above Lake Atitlán, about 3-5 km. west of Panajachel, Sololá, 2,100 m., Williams, Molina and Williams 25314, type (F).

In addition to the indument which distinguishes this variety from the glabrous $J$. macrantha, it also differs in its shorter, broader leaves, its shorter inflorescences, and its lanceolate, acute calyx lobes.

Justicia magniflora (Blake) D. Gibson, comb. nov. Dicliptera magniflora Blake, Contr. Gray Herb. 52: 98.1917 (type from British Honduras, Peck 622a). Beloperone crenata Standley, Carn. Inst. Wash. Publ. 461: 88. 1935, non Jacobinia crenata Leonard, Field Mus. Bot. 18: 1223. 1938. Beloperone magniflora Leonard, Carn. Inst. Wash. Publ. 461: 234. 1936.

Justicia montana (Standley \& Leonard) D. Gibson, comb. nov. Beloperone montana Standley \& Leonard, Field Mus. Bot. 23: 239. 1947.

Pollen grains are prolate, 4-porate, with rows of insulae surrounding the apertures (fig. 10A).

\section{Justicia pedicellata D. Gibson, sp. nov.}

Frutices usque ad $2 \mathrm{~m}$. vel ultrae, folia lanceolata, lanceolato-oblonga vel elliptica, acuminata, basi attenuata, glabra; inflorescentia axillaris vel terminalis, subumbelliformis; flores pedicellati, pedicelli $2-5 \mathrm{~cm}$. longi; bracteae ovatae vel 


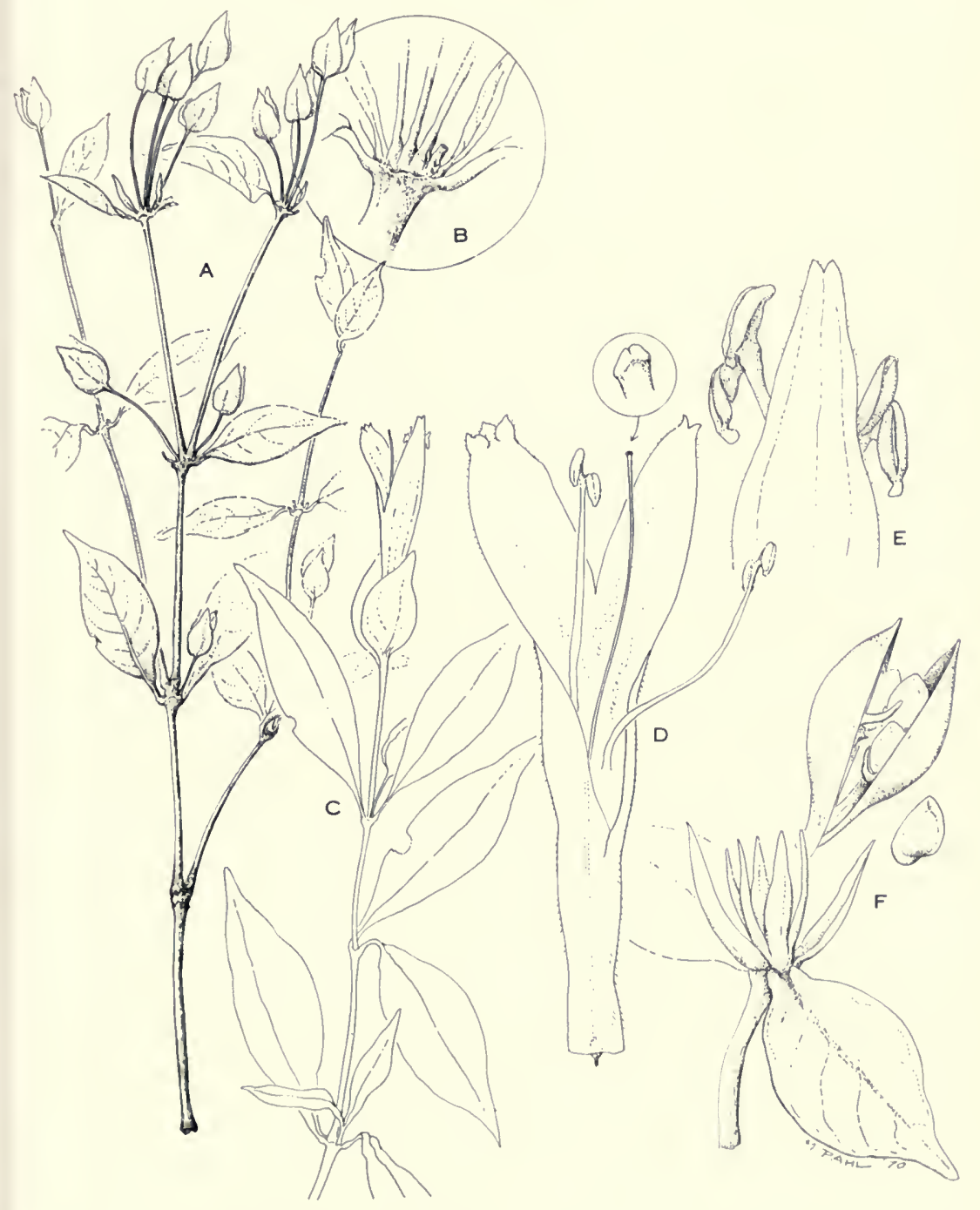

FIG. 4. Justicia pedicellata. A, habit, $\times 1 / 2 ; \mathbf{B}$, detail of pedicels in umbelliform arrangement, $\times 1 \frac{1}{2} ; \mathbf{C}$, section of flowering branch with flower, $\times 1 ; D$, corolla with stamens and style, $\times 2 \frac{1}{2} ; \mathbf{E}$, upper lip of corolla and exserted anthers, $\times 4 ; F$, opened bracts showing bracteoles, calyx, and capsule with seeds, $\times 21 / 2$. 
lanceolatae, acuminatae, glabrae, $12-24 \mathrm{~mm}$. longae et 7-12 $\mathrm{mm}$. latae, basi subcordatae; bracteolae lanceolatae vel ellipticae; calyces lobi 5 , lineares vel lineari-lanceolati, glabri, acuminati, $6-7 \mathrm{~mm}$. longi; corolla rubra, plus minusve 3.5 $\mathrm{cm}$. longa; stamina corolla subaequilonga, thecae antherarum $2-2.5 \mathrm{~mm}$. longae; pollen biporatum; capsula glabra, 10-12 $\mathrm{mm}$. longa; semina complanata, puberula.

Branching shrubs $2 \mathrm{~m}$. tall or more, the stems and branches terete, glabrous; leaves on glabrous petioles $0.2-1 \mathrm{~cm}$. long, the blades lanceolate, lance-oblong, or elliptic, 3-9 $\mathrm{cm}$. long, 1-3 cm. wide, acuminate to long-acuminate, attenuate to the base, glabrous on both surfaces, the cystoliths conspicuous; inflorescences axillary or terminal, the flowers on erect pedicels $2-5 \mathrm{~cm}$. long, solitary or 2-several in an umbelliform arrangement; bracts ovate to lanceolate, $12-24 \mathrm{~mm}$. long, 7-12 $\mathrm{mm}$. wide, acuminate to long-acuminate, the base rounded to subcordate, venose, glabrous; bracteoles lanceolate or elliptic, about $10 \mathrm{~mm}$. long, ciliolate; calyx lobes 5 , linear or linear-lanceolate, acuminate, $6-7 \mathrm{~mm}$. long, glabrous; corolla red, about $3.5 \mathrm{~cm}$. long, the tube only slightly ampliate above, minutely pubescent outside, the lips 10-13 mm. long, the posterior lip bidentate, the anterior one trilobate, the lobes $1 \mathrm{~mm}$. long, acute; stamens almost equalling the corolla, the filaments inserted below the throat, the anthers $2-2.5 \mathrm{~mm}$. long, one theca below the other on the connective, at least the lower one calcarate; pollen 2-porate, ellipsoidal, isopolar, bilateral; style exserted, the stigma minutely bilobate; capsule 10-12 $\mathrm{mm}$. long, glabrous; seeds compressed, puberulous.

Guatemala: Alta Verapaz, Samac to Chamá, about 1,200 m., Harry Johnson 780, type (F); between Finca Chimoté near Rubeltein and Finca Cubilgüitz, 300-500 m., Steyermark 44196; Cacao, Finca Trece Aguas, alt. ca. 300 m., G. P. Goll 103.

Justicia pedicellata resembles the Brazilian $J$. thunbergioides (Lindau) Leonard. However, according to the photograph of the type of the latter (F.M. Neg. 8949, Malme 3026), and the original description of Beloperone thunbergioides Lindau (Bull. Herb. Boiss. ser. 2, 5: 372. 1905), the leaves are broadly ovate, the bracts shortacuminate, the pedicels puberulent and only $1-1.5 \mathrm{~cm}$. long, the sepals $10 \mathrm{~mm}$. long, and the capsule $18 \mathrm{~mm}$. long.

\section{Justicia pilifera D. Gibson, sp. nov.}

Herbae ramosae usque $2 \mathrm{~m}$. altae, omnino pilosae; folia lanceolata vel lanceolato-elliptica, acuminata, basi acuta; inflorescentiae axillares et terminales, cymosae vel breviter spicatae; calyx 4-lobatus lobi lineari vel anguste linearilanceolati, acuminati, glanduloso-pubescentes, 5-10 mm. longi; corolla alba, 3-4 $\mathrm{cm}$. longa; theca infera conspicue calcarata; pollen biporatum; capsula glabra, 15-18 mm. longa.

Branching shrubs to $2 \mathrm{~m}$. tall, about $8 \mathrm{~cm}$. in diameter at the base, more or less pubescent throughout, densely so on uppermost stems; leaves short-petiolate, the blades lanceolate to lance-elliptic, acuminate, acute at base, mostly $6-12 \mathrm{~cm}$. long, $2-5 \mathrm{~cm}$. wide, the margins undulate or entire, sparsely pubescent or glabrate above or the pubescence confined to costae and veins, softly and usually densely pubescent beneath; inflorescences axillary and terminal, the flowers sessile or on short 
pedicels in cymes or in short, few-flowered spikes, the rachis usually less than $3 \mathrm{~cm}$. long, densely pubescent; bracts and bracteoles subulate, 3-5 $\mathrm{mm}$. long, pubescent; calyx segments 4 , linear or narrowly linear-lanceolate, acuminate, accrescent, $5-10$ $\mathrm{mm}$. long, glandular-pubescent; corolla white or white spotted with buff, 3-4 cm. long, somewhat fusiform in bud, the tube slender, scarcely ampliate above, more or less pubescent with both glandular and eglandular hairs, the lips $1-1.5 \mathrm{~cm}$. long, the upper one minutely bifid, the lower one very shallowly trilobate; stamens about equalling the upper lip, filaments puberulent, inserted near base of corolla tube, the anthers bithecous, $1-1.5 \mathrm{~mm}$. long, the lower theca conspicuously calcarate; pollen 2-porate, isopolar, bilateral; style filamentous, glabrous; ovary glabrous; disc conspicuous, irregularly lobate; capsule glabrous, clavate, stipiform at base, 15-18 mm. long, containing 4 lenticular, pubescent seeds.

Guatemala: En foresta alta, en orillando el camino para El Remata, a km. 66, lado poniente, Parque Nacional de Tikal, about 200 m., Rolando Tún Ortiz 1529, type (F).

This plant superficially resembles $J$. eburnea D. Gibson, which is glabrous throughout and also differs in its larger leaves, 6-16 cm. long, 2-7 cm. wide, shorter calyces, $3-4 \mathrm{~mm}$. long, and shorter corollas, $2.5-3 \mathrm{~cm}$. long.

Justicia purpusii (Brandg.) D. Gibson, comb. nov. Beloperone purpusi Brandegee, Zoe 5: 172. 1903.

Justicia silvicola D. Gibson, sp. nov.

Herbae simplices aut leviter ramosae glabrae, 50-60 cm. altae; folia lanceolatoelliptica vel elliptico-ovata, acuminata; inflorescentiae subcapitatae, terminales vel axillares; bracteae clavatae vel spatulatae, $8-11 \mathrm{~mm}$. longae; calyx 5-6 mm. longus, quinquelobatus, lobi lineari, acuminati; corolla alba, plus minusve $2 \mathrm{~cm}$. longa; theca infera conspicue calcarata; pollen prolatum, quadriporatum; capsula clavata, plus minusve $1 \mathrm{~cm}$. longa; semina 4 , compressa.

Simple or sparsely branching herbs $50-60 \mathrm{~cm}$. tall, the stems glabrous; leaves on petioles 1-1.5 cm. long, the blades lanceolate-elliptic to elliptic-ovate, mostly 5-12 cm. long, 2.5-4 cm. wide, acuminate, attenuate or acute at the base, glabrous, conspicuously paler beneath, the cystoliths numerous; inflorescences subcapitate, terminal or axillary; bracts clavate to spathulate, glabrous, 8-11 mm. long, bracteoles similar but smaller; calyx 5-6 mm. long, the 5 segments linear, acuminate, glabrous; corolla white, glabrous, about $2 \mathrm{~cm}$. long; stamens about equalling the lips, the anthers $1.5-2 \mathrm{~mm}$. long, thecae one below the other on the connective, the lower one conspicuously calcarate; pollen 4-porate, the insulae scattered and the rows widely spaced (fig. 10B); capsules clavate, stipitate, glabrous, about $1 \mathrm{~cm}$. long, containing 4 compressed, ovate, minutely puberulent seeds borne on truncate retinacula.

Guatemala: Izabal, Cerro San Gil, uppermost ridges and summit, 1,200-1,300 m., Steyermark 41984, type (F). 
The bracts and corollas resemble those of $J$. corynimorpha D. Gibson and the leaves in shape and size are similar to those of $J$. carthagenensis Jacq. However, the capsules of both of those species are puberulent, and the seeds are subglobose instead of compressed.

Justicia straminea D. Gibson, nom. nov. Beloperone pringlei Watson, Proc. Am. Acad. 25: 160. 1890 (Pringle 2548, type, Nuevo León, Mexico), non Justicia pringlei Robinson, Proc. Am. Acad. 26: 173. 1891.

Justicia sulfurea (Donn.-Sm.) D. Gibson, comb. nov. Dianthera sulfurea Donn.-Sm. Bot. Gaz. 35: 6. 1903.

This species is known only from the type collection, Santa Rosa, Guatemala, 1,200 m., Heyde \& Lux 6215. The lectotype specimen is U.S. National Museum No. 1320313. The muticous thecae are more or less divergent, one being placed higher than the other on the connective; the pollen grains are 2-porate and bilateral.

Justicia tenera (Turrill) D. Gibson, comb. nov. Beloperone tenera Turrill, Kew Bull. 1922: 187. 1922 (type from Trinidad, W. I., R. O. Williams). B. fragilis Robins. (non Mart.) Proc. Am. Acad. 27: 183. 1892 (type from San Luis Potosí, Mexico, C. G. Pringle 3933).

The pollen grains are 2-porate, bilateral, isopolar, with 2 rows of insulae on either side of each aperture.

Justicia tinctoria (Hemsl.) D. Gibson, comb. nov. Sericographis tinctoria Oerst. Vid. Medd. Kjoebenhavn 1854: 150. 1855. Jacobinia tinctoria Hemsl. Biol. Cent. Am. Bot. 2: 522. 1882.

The pollen grains are 2 -porate, isopolar, and bilateral, with 2 rows of insulae on either side of each aperture (fig. 8B).

Justicia urophylla (Lindau) D. Gibson, comb. nov. Beloperone urophylla Lindau in Pittier, Anal. Inst. Fis.-Geog. Costa Rica 9: 189. 1898; Prim. Fl. Costaricensis 2: 316. 1900.

The pollen grains are 2-porate, isopolar, bilateral.

\section{ODONTONFMA Nees}

Odontonema hondurensis (Lindau) D. Gibson, comb. nov. Diateinacanthus hondurensis Lindau, Bull. Herb. Boiss. 2(5): 369. 1905. O. paniculiferum Blake, Contr. Gray Herb. 52: 104. 1917. 
Although the inflorescences of Diateinacanthus form lax panicles instead of narrow, racemiform panicles, other morphological characters are the same. This transfer is further justified by pollen studies showing the pollen grains of Diateinacanthus and Odontonema to be identical, both 3 -colporate, subprolate, with a granular membrane, the sexine reticulate.

\section{POIKILACANTHUS Lindau}

Poikilacanthus pansamalanus (Donn.-Sm.) D. Gibson, comb. nov. Beloperone pansamalana Donn.-Sm. Bot. Gaz. 13: 75. 1888.

This species, known only from the type locality, $1,300 \mathrm{~m}$., Pansamala, Alta Verapaz, Guatemala (Tuerckheim 732, type), superficially resembles plants in the Justicia-Jacobinia complex. However, the anisophyllous leaves and the polyporate pollen grains that are covered with densely spaced polygonal insulae (fig. 11), definitely place it in Poikilacanthus.

\section{Poikilacanthus skutchii D. Gibson, sp. nov.}

Frutices debiles usque ad $2 \mathrm{~m}$. alti; folia elliptica vel lanceolato-elliptica aut ovato-elliptica abrupte acuminata basi attenuata; inflorescentiae terminales cymosae breviter pedunculatae pauciflorae, flores sessiles vel breviter pedicellati; bracteae spathulatae; lobi calyces 5 , lineari-oblongi, acuti; corolla rubra $4-4.5 \mathrm{~cm}$. longa; stamina corolla subaequilonga, thecae calcaratae; pollen polyporatum prolatum, insulae obtectae; capsula glabra, semina 4 .

Weak shrubs to $2 \mathrm{~m}$. tall, the stems and young branches pubescent or glabrate; leaves anisophyllous, on petioles $0.5-1.5 \mathrm{~cm}$. long, the blades ellip tic to lanceelliptic or rarely ovate-elliptic, apex usually abruptly acuminate, attenuate to the base, glabrous or with some scattered pubescence along the veins; inflorescence terminal, cymose, short-pedunculate, the flowers few, sessile or short-pedicellate; bracts spathulate, 7-9 $\mathrm{mm}$. long, 3-4 $\mathrm{mm}$. broad, more or less glandular-puberulent; bracteoles similar but a little smaller; calyx lobes 5 , linear-oblong, acute, 6-7 $\mathrm{mm}$. long; corolla red, $4-4.5 \mathrm{~cm}$. long, only a little ampliate above, pubescent outside, the lips 1.5-2 cm. long, the posterior lip shortly bilobate, the anterior one trilobate, the lobes about $2 \mathrm{~mm}$. long; stamens about equalling the corolla lips, the filaments attached below the throat; anthers $2-3 \mathrm{~mm}$. long, one theca lower than the other on the connective, both minutely calcarate; pollen polyporate, prolate, covered with densely spaced polygonal insulae; style exserted, the stigma obscurely bilobate; capsule glabrous, about $1.5 \mathrm{~cm}$. long, containing 4 smooth, compressed, orbicular seeds.

Guatemala: Quezaltenango, Volcán Zunil, 2,400 m., Skutch 936, type (F); San Marcos, wet forest, Barranco Eminencia, above San Rafael Pie de la Cuesta, 2,100-2,400 m., Standley 68650; between San Rafael Pie de la Cuesta and Palo Gordo, alt. 1,800-2,400 m., 

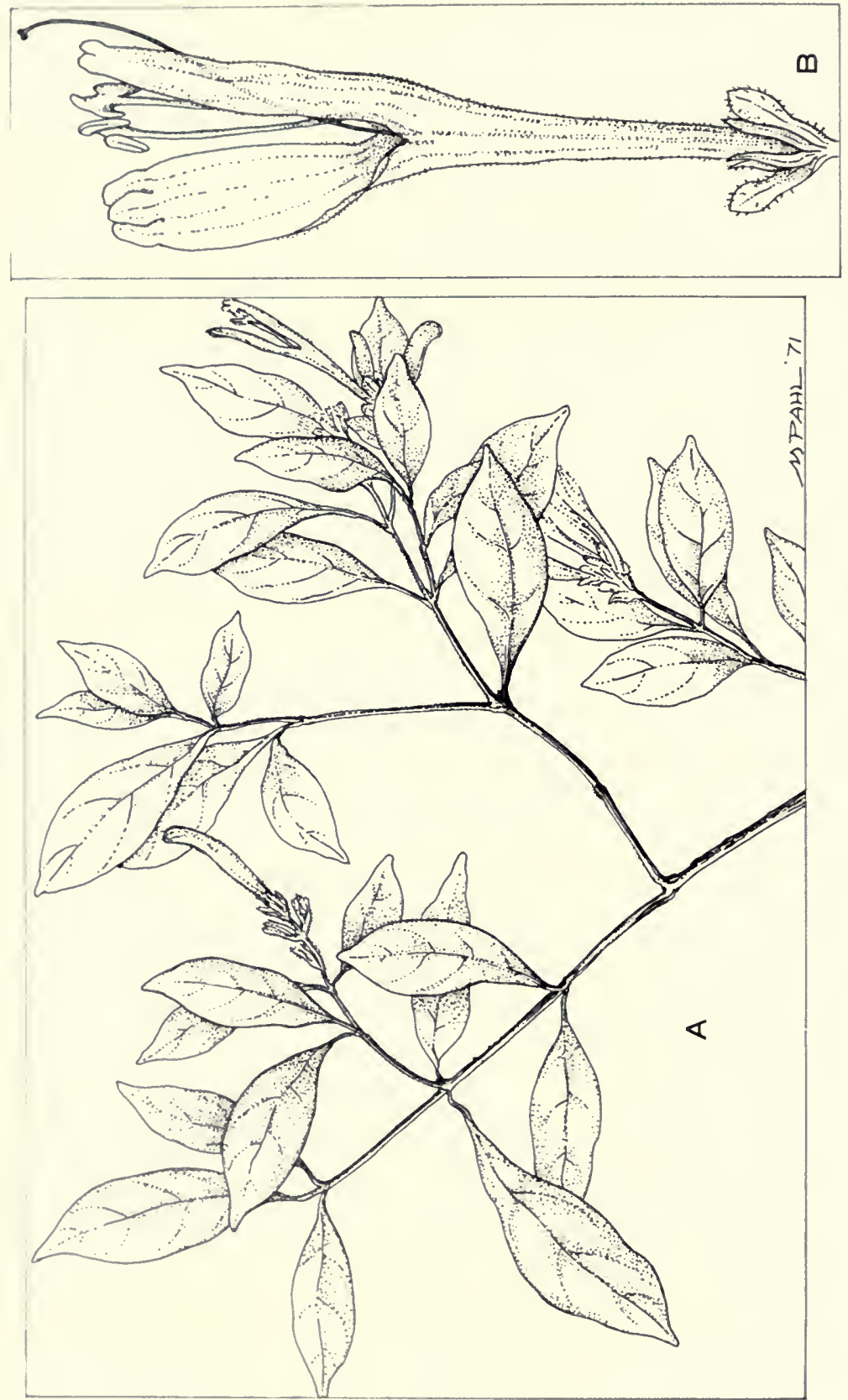

त्र 
Williams, Molina, \& Williams 25965, 25771, and 26285; montane cloud forest area on outer slopes of Tajumulco Volcano, Sierra Madre Mountains, about 2,300 m., Williams et al. 26968.

These plants have been misidentified in herbaria as Beloperone pansamalana Donn.-Sm. (=Poikilacanthus pansamalanus (Donn.Sm.) D. Gibson), which has bracts that are cuneiform above, tapering abruptly to a clawlike base, and thecae that are curved, muticous, and remote from each other on the connective.

\section{RAZISEA Oersted}

\section{Razisea breviflora D. Gibson, sp. nov.}

Herbae usque ad $80 \mathrm{~cm}$. vel ultrae; caules leviter pubescentes; folia oblongoovata vel elliptica acuminata basi rotundata vel acuta subtus pubescentia aut subpubescentia; inflorescentia anguste thyrsiformis, rachis dense puberulens, flores numerosi, cymae bi-triflorae; bracteae lanceolatae, puberulentes, 7-10 $\mathrm{mm}$. longae; calyx base puberulens, segmenta linearia acuta 7-8 $\mathrm{mm}$. longa; corolla aurantiaca $2.5 \mathrm{~cm}$. longa tubo ampliato; stamina 2 longe exserta, antherae monothecae muticae, $4 \mathrm{~mm}$. longae; capsula ignota.

Herbaceous plants to $80 \mathrm{~cm}$. or more tall, the stems more or less pubescent; leaves on puberulent petioles $1-4 \mathrm{~cm}$. long, the blades oblong-ovate to elliptic, acuminate, rounded or acute at base, 6-12 cm. long, 3-6 cm. wide, pubescent beneath on costae and veins, glabrate or with some scattered pubescence on both surfaces, with about 7 pairs of lateral veins; inflorescence terminal, narrowly thyrsiform, subtended by a pair of greatly reduced, sessile or subsessile leaves, the rachis densely puberulent; the flowers numerous, short-pedicellate, in 2-3-flowered cymes; bracts lanceolate, 7-10 $\mathrm{mm}$. long, bracteoles similar but smaller, both very minutely puberulent; calyx $7-8 \mathrm{~mm}$. long, minutely puberulent, at least near the base, the segments narrowly linear, acute; corolla about $2.5 \mathrm{~cm}$. long, orangeyellow, the tube slightly curved, gradually ampliate, the throat about $5 \mathrm{~mm}$. broad, the upper lip narrow, 5-6 $\mathrm{mm}$. long, minutely fimbriate, the lower lip broad, very shallowly trilobate; stamens 2, long-exserted, the anthers monothecous, linearoblong, muticous, about $4 \mathrm{~mm}$. long; pollen 2-porate, bilateral, spheroidal, the sexine verrucose with blunt spines; style filiform, exserted, the stigma minutely bifid; capsule unknown.

Costa Rica: Dense, wet forest, south slope of Volcán Barba, Prov. Heredia, 1,950 m., Hatheway 1270, type (F).

Differs from $R$. spicata. Oerst. in its much smaller leaves and smaller flowers with orange-yellow corollas; the corollas of $R$. spicata are bright red, $4-6 \mathrm{~cm}$. long. $R$. citrina $\mathrm{D}$. Gibson (described below) has a broader inflorescence composed of pedunculate, compound cymes, and lemon yellow corollas $3.5-4.5 \mathrm{~cm}$. long. 


\section{Razisea citrina D. Gibson, sp. nov.}

Herbae usque ad 2 m., glabrae; folia inflorescentiae ovata sessiles aut subsessiles; folia caulium petiolata, lanceolata vel lanceolato-ovata aut late elliptica acuminata glabra; inflorescentia late thyrsiformis vel anguste paniculata, flores numerosi cymae bi-triflorae; pedicelli $5-15 \mathrm{~mm}$. longi; bracteae subulatae; calyx glabrum, segmenta linearia acuminata, 8-10 mm. longa; corolla citrina glabra $3.5-4.5 \mathrm{~cm}$. longa, tubo ampliato; stamina 2 longe exserta, antherae monothecae muticae $5 \mathrm{~mm}$. longae; capsula glabra $2.5 \mathrm{~cm}$. longa; semina 4 lentiformes verrucosa.

Herbaceous plants to $2 \mathrm{~m}$. tall; glabrous throughout; one or more pairs of leaves subtending the inflorescence, ovate, sessile or subsessile, of ten more or less clasping, one pair much reduced, sometimes only about $2 \mathrm{~cm}$. long, $1.5 \mathrm{~cm}$. wide, the other pair 4-12 cm. long, 3.5-6 cm. wide, the lower leaves petiolate, the blades broadly lanceolate, lance-ovate, or broadly elliptic, $14-18 \mathrm{~cm}$. long, 5-9 cm. wide, acuminate, acute or attenuate to the base, with 12-13 pairs of lateral veins, glabrous on both surfaces; inflorescences terminal, pedunculate, the flowers arranged in cymes, these branching and forming broad thyrses or narrow panicles 20-30 cm. long, 5-7 cm. broad, each cyme usually 2-3-flowered; pedicels 5-15 mm. long; bracts subulate, $3-5 \mathrm{~mm}$. long, bracteoles $1-2.5 \mathrm{~mm}$. long; calyx 8-10 mm. long, glabrous, the segments narrowly linear, acuminate; corolla lemon-yellow, glabrous, $3.5-4.5 \mathrm{~cm}$. long, the tube curved, gradually ampliate, the throat 5-11 $\mathrm{mm}$. wide near the top, the upper lip 7-9 mm. long, 3-4 mm. wide, acute, appearing entire but actually very minutely fimbriate, the lower lip broad, shallowly trilobate, the lobes ovate, acute; stamens 2, long-exserted, the anthers monothecous, linearoblong, muticous, about $5 \mathrm{~mm}$. long; pollen 2-porate, bilaterai, spheroidal, the sexine verrucose with blunt spines; style filiform, exserted, stigma minutely bifid; capsule glabrous, slender-clavate, about $2.5 \mathrm{~cm}$. long, the stipiform portion about $1.5 \mathrm{~cm}$. long, containing 4 lenticular, verrucose seeds.

Costa Rica: Evergreen forest between Agua Buena and San Vito de Java, Prov. Puntarenas, 1,200 m., Jimenez 2475, type (F).

Differs from R. spicata Oerst. and $R$. breviflora D. Gibson in its much broader inflorescences composed of pedunculate compound cymes; further, the corollas of $R$. spicata are bright red, $4-6 \mathrm{~cm}$. long, while those of $R$. breviflora are orange-yellow and only $2.5 \mathrm{~cm}$. long.

\section{RUELLIA L.}

Ruellia abbreviata D. Gibson, nom. nov. Cryphiacanthus lacteus var. acaulis Nees in DC. Prodr. 11: 198. 1847. Ruellia lactea Cav. var. acaulis Hemsley, Biol. Cent. Am. 2: 506. 1882, non $R$. acaulis R. Browne, Nees, Badillo, nec Ruiz ex Nees.

Nees var. acaulis is distinct from $R$. lactea but requires a new name when raised to specific rank.

Nees cited two specimens under Cryphiacanthus lacteus var. acaulis. The first, Erenberg 627, was in Berlin. The second, Galeotti 
913, from Oaxaca, Mexico, is in Kew; inasmuch as the first specimen cited has presumably been destroyed, I select the second as lectotype.

\section{Ruellia latibracteata D. Gibson, sp. nov.}

Herbae suffruticosae usque ad $2 \mathrm{~m}$.; caules teretia; folia late lanceolata vel oblongo-lanceolata acuminata glabra; inflorescentiae spicatae terminales pedunculatae confertiflorae; bracteae ovatae late ovatae vel orbiculares breviter acuminatae 1-2 cm. longae, venosae ciliatae; bracteolae lanceolatae vel falcatae, acuminatae vel abrupte caudato-acuminatae, 1-1.5 cm. longae longe ciliatae; lobi calyces 5, 4-6 $\mathrm{mm}$. longi lineares longe ciliati; corolla atrorosea, 4-5 cm. longa; anthera $3 \mathrm{~mm}$. longa; capsula late obovata, semina lentiformes, 8-10.

Suffruticose plants 1-2 m. tall, branching, the stems terete, bifariously pubescent or glabrate; leaves on petioles $1.5-6 \mathrm{~cm}$. long, the blades broadly lanceolate or oblong-lanceolate, acuminate, rounded or acute at base and of ten abruptly decurrent on the petiole, mostly $8-15 \mathrm{~cm}$. long, 3-7 cm. wide, glabrous, the cystoliths numerous; inflorescences terminal, spicate, the peduncles about $0.5 \mathrm{~cm}$. long, the spikes 2-7 cm. long, densely flowered; bracts ovate, broadly ovate, or orbicular, short-acuminate, mostly 1-2 cm. long, 1-2 cm. broad, venose, usually ciliate; bracteoles lanceolate to falcate, $1-1.5 \mathrm{~cm}$. long, acuminate to abruptly caudateacuminate, conspicuously long-ciliate; calyx 4-6 $\mathrm{mm}$. long, the 5 segments linear, acuminate, long-ciliate; corolla rose-red or rose-purple, puberulent outside, 4-5 $\mathrm{cm}$. long, the narrow basal portion of the tube a little shorter than the rather abruptly dilated throat, the limb about $1 \mathrm{~cm}$. long, the lobes ciliolate; stamens a little exserted, the anthers about $3 \mathrm{~mm}$. long; pollen 3 -porate, spheroidal; style pubescent; capsule broadly obovate, short-stipitate, pubescent, containing 8-10 lenticular, pale-marginate seeds $3-4 \mathrm{~mm}$. long.

Honduras: Depto. Paraíso, bosque de nubes de Montaña Apauhis sobre Danlí, 1,600 m., Molina 5119, type (F); trail, Danlí to Finca Emilia, Carlson 2564; Depto. Olancho, 500-900 m., Molina 8385, Standley 18346 and 18574; Depto. Yoro, 1,100 m., Molina 6885.

Sometimes confused in herbaria with $R$. matagalpae Lindau, which has leaflike bracts $3-4 \mathrm{~cm}$. long, calyces $9-13 \mathrm{~mm}$. long, and corollas with the basal portion of the tube much longer than the ampliate throat.

\section{Ruellia longissima D. Gibson, sp. nov.}

Herbae suffruticosae usque ad $1.5 \mathrm{~m}$. altae, caules quadrangulares pubescentes; folia oblongo-elliptica, acuminata, basi attenuata; inflorescentiae cymae pauciflorae, pedunculi perlongi; lobi calyces 5 , lineari acuminati glandulari-pubescentes; corolla lavandula aut alba, $2-2.5 \mathrm{~cm}$. longa; stamina inclusa; capsula clavata, glandulosipuberulens; semina lentiformes, 6-8.

Erect, suffruticose, branching plants to $1.5 \mathrm{~m}$. tall, the stems more or less quadrangular, pubescent; leaves on petioles 1-3 cm. long, the blades oblong-elliptic, mostly $9-20 \mathrm{~cm}$. long, $3-5 \mathrm{~cm}$. wide, acuminate, attenuate to the base and somewhat decurrent on the petiole, glabrous above, pubescent beneath on costae and 
veins, the margins entire or somewhat undulate; inflorescences axillary, simple or branching, the peduncles commonly $15-30 \mathrm{~cm}$. long, conspicuously angled, pubescent or puberulent, the flowers sessile or short-pedicellate in usually 3-4-flowered cymes, the cymes sometimes clustered and the inflorescence then appearing fasciculate; bracts subtending the inflorescence foliaceous, linear or narrowly elliptic, $0.5-1 \mathrm{~cm}$. long, the involucral bracts short, unequal, the outer ones linear-oblong, 2-3 $\mathrm{mm}$. long, the inner ones narrowly triangular, 1-2 mm. long; calyx 4-6 $\mathrm{mm}$. long, the 5 segments linear, acuminate, glandular-pubescent, of ten reflexed in age; corolla lavender or white with lavender lobes, $2-2.5 \mathrm{~cm}$. long, more or less pubescent outside, the narrow basal portion of the tube equalling or a little shorter than the abruptly ampliate throat; stamens included, the anthers about $1 \mathrm{~mm}$. long; pollen 3 -porate, spheroidal; style more or less pubescent, capsules $1-1.4 \mathrm{~cm}$. long, clavate, glandular-puberulent, containing 6-8 lenticular seeds about $2 \mathrm{~mm}$. in diameter.

Costa Rica: Pcia. Limón, $250 \mathrm{~m}$., unos $2.5 \mathrm{~km}$. al Este de Guápiles, Jiménez 2098, type (F); en bosque vecino al Río Toro Amarillo, a $5.5 \mathrm{~km}$. al So. del Guápiles, Pcia. Limón, 300 m., Jiménez 1033.

Sometimes confused with $R$. stemonacanthoides (Oerst.) Hemsley, which has shorter peduncles $(2-10 \mathrm{~cm}$. long), much larger flowers (the calyces $6-10 \mathrm{~mm}$. long, and corollas $3-4.5 \mathrm{~cm}$. long), with the slender lower portion of the corolla tube longer than the throat, and larger capsules $(1.5-2 \mathrm{~cm}$. long) usually containing about 12 seeds.

\section{Ruellia longissima var. glabra D. Gibson, var. nov.}

A $R$. longissima differt glabra, foliis brevioribus et latioribus, ovatis vel elliptico-ovatis.

Differs from $R$. longissima in its glabrous stems, leaves, calyces, corollas, and capsules, and in its shorter, broader leaves that are ovate to elliptic-ovate, 7-14 $\mathrm{cm}$. long and 4.5-7 cm. wide, acuminate at the apex, but rounded at the base.

Costa Rica: Prov. Puntarenas, floodplain forest near the Tinoco Station, $100 \mathrm{ft}$. area between the Río Esquinas and Palmar, Paul H. Allen 5481, type (F); alt. 30 m., between Golfo Dulce and Río Térraba, Skutch 5287 and 5335.

Ruellia longituba D. Gibson, nom. nov. Cryphiacanthus macrosiphon Nees in DC. Prodr. 11:198. 1847. Ruellia macrosiphon Donn.-Sm. Enum. Pl. Guat. 1: 32. 1889, non Ruellia macrosiphon Kurz, Journ. Royal As. Soc. Bengal 42: 92. 1873.

FIG. 6. (opposite) Ruellia pratensis. A, habit, $\times 1 / 2 ; \mathbf{B}$, complete flower and one corolla opened to show stamens, $\times 1 \frac{1}{2}$ (inset shows detail of anthers, greatly enlarged); C, bracts and calyx enclosing pistil, $\times 2$ (detail of stigma greatly enlarged); D, bracts and calyx enclosing immature capsule, $\times 1 \frac{1}{2} ; \mathbf{E}$, seed, $\times 15$. 
Ruellia pratensis D. Gibson, sp. nov.

Herbae suffruticosae erectae vel ascendentes pilosae usque ad $20 \mathrm{~cm}$.; folia ovata acuta vel obtusa pilosa, subsessiles vel breviter petiolata; inflorescentiae sessiles; bracteae anguste lanceolatae; lobi calyces 5 , anguste lineari, pilosi; corolla 3-4 cm. longa; stamina inclusa; capsula glabra, ellipsoidea, ca. $14 \mathrm{~mm}$. longa.

Erect or ascending, herbaceous or suffruticose perennials, commonly 10-20 $\mathrm{cm}$. tall, more or less pilose throughout; leaves subsessile to short-petiolate, the blades ovate or broadly ovate, mostly $1.5-4 \mathrm{~cm}$. long, 1-2 cm. wide, acute or obtuse, acute at base or sometimes rather abruptly decurrent on the petiole, sparsely or densely pilose on both surfaces, the margins entire or somewhat crenate-undulate; inflorescences axillary and terminal, sessile; bracts narrowly lanceolate, mostly 3-8 $\mathrm{mm}$. long; calyx 14-18 $\mathrm{mm}$. long, the 5 segments narrowly linear, alxly longpilose; corolla 3-4 cm. long, pubescent outside, the narrow part of the tube about 1 cm. long; stamens included; pollen 3-porate, spheroidal; style pubescent; capsule glabrous, ellipsoidal, about $14 \mathrm{~mm}$. long, containing 8-9 lenticular seeds.

Guatemala: praderas de Guatemala, 1,400 m., Tonduz 620, type (F); Guatemala City, Mrs. B. B. Lewis 299; Guatemala, 5,000 ft., $W$. C. Shannon 4713; Huehuetenango, Chaculá, 1,300-1,600 m., C. \& E. Seler 2984. Mexico: Temascaltepec, 1,900 m., Hinton 1231.

These plants have been confused in herbaria with $R$. humifusa (Oerst.) Hemsl. and with $R$. geminiflora HBK. The former species has longer corollas (about $5 \mathrm{~cm}$. long) in which the narrow portion of the tube is at least $2 \mathrm{~cm}$. long; the latter species has pubescent capsules only $7-10 \mathrm{~mm}$. long.

\section{SIPHONOGLOSSA Oersted}

Siphonoglossa sessilis (Jacq.) D. Gibson, comb. nov. Justicia sessilis Jacq. Enum. Pl. Carib. 11. 1760. Rhytiglossa sessilis Nees in DC. Prodr. 11: 345. 1847. Siphonoglossa ramosa Oerst. Vid. Medd. 1854: 159-160, t. 5, f. 34, 35. 1855. S. discolor Blake, Contr. U. S. Nat. Herb. 24: 24. 1922. S. hondurensis Standley \& Steyermark, Ceiba 3: 131. 1952.

FIG. 7. (opposite) Scanning electron microscope photographs of pollen grains of A, Justicia corynimorpha, $\times 1,720 ; \mathrm{B}$, Justicia eburnea, $\times 2,265$. Photographs courtesy of the Department of Biological Sciences, University of Illinois at Chicago Circle. 


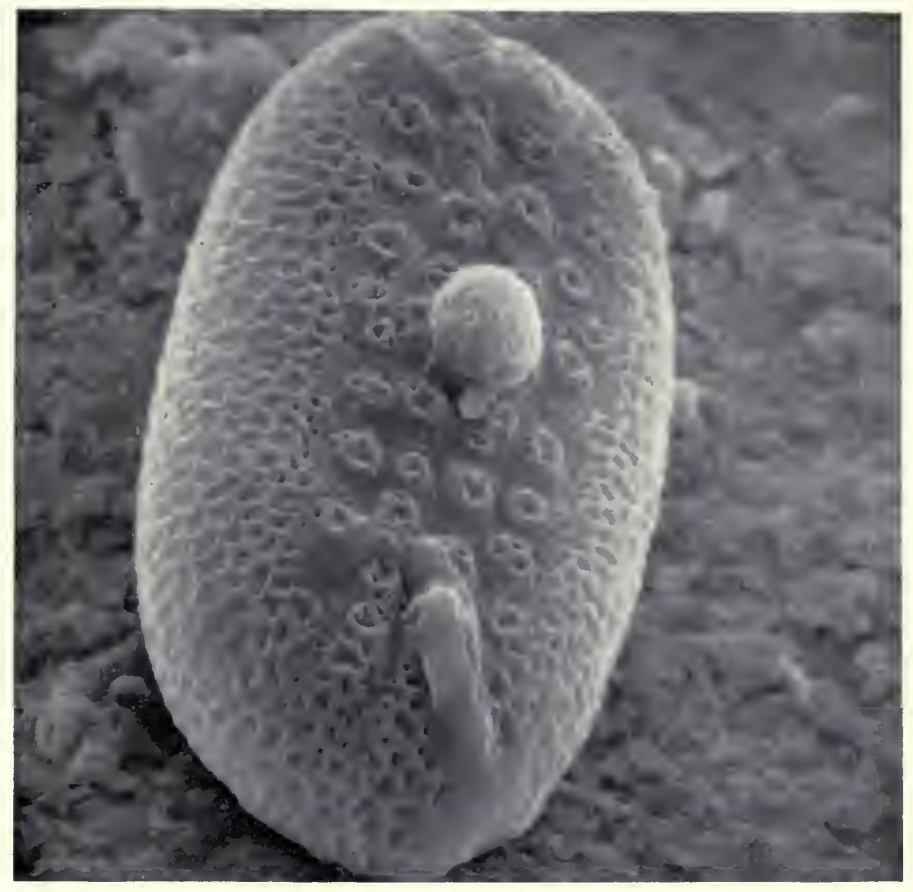

A

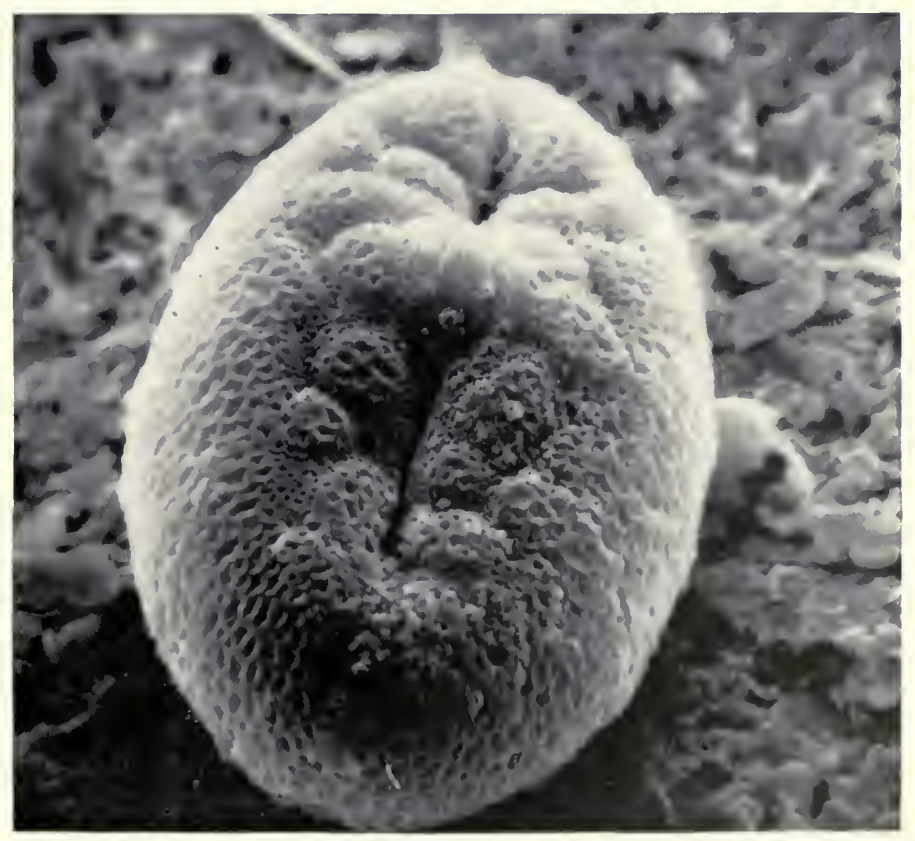




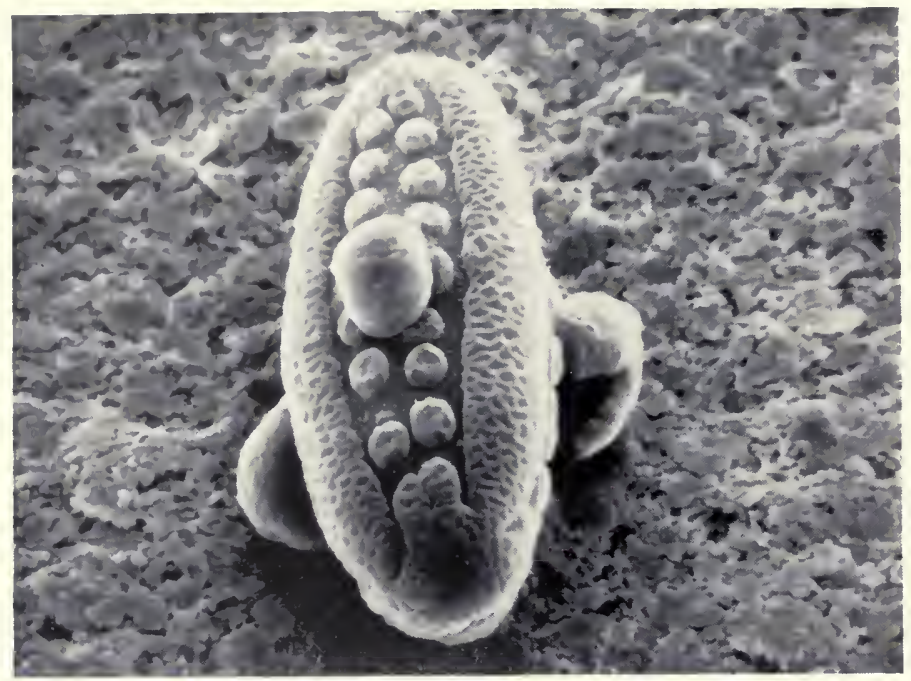

A

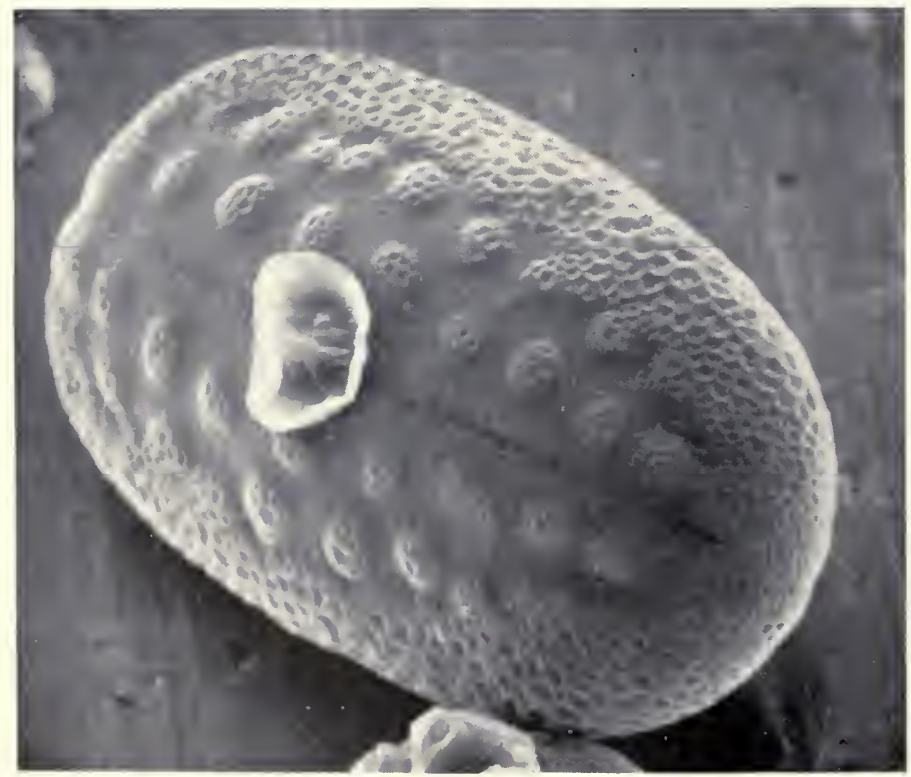

B

FIG. 8. Scanning electron microscope photographs of pollen grains of A, Justicia grandifolia, $\times 980 ; \mathrm{B}$, Justicia tinctoria, $\times 1,980$. Photographs courtesy of the Department of Biological Sciences, University of Illinois at Chicago Circle. 

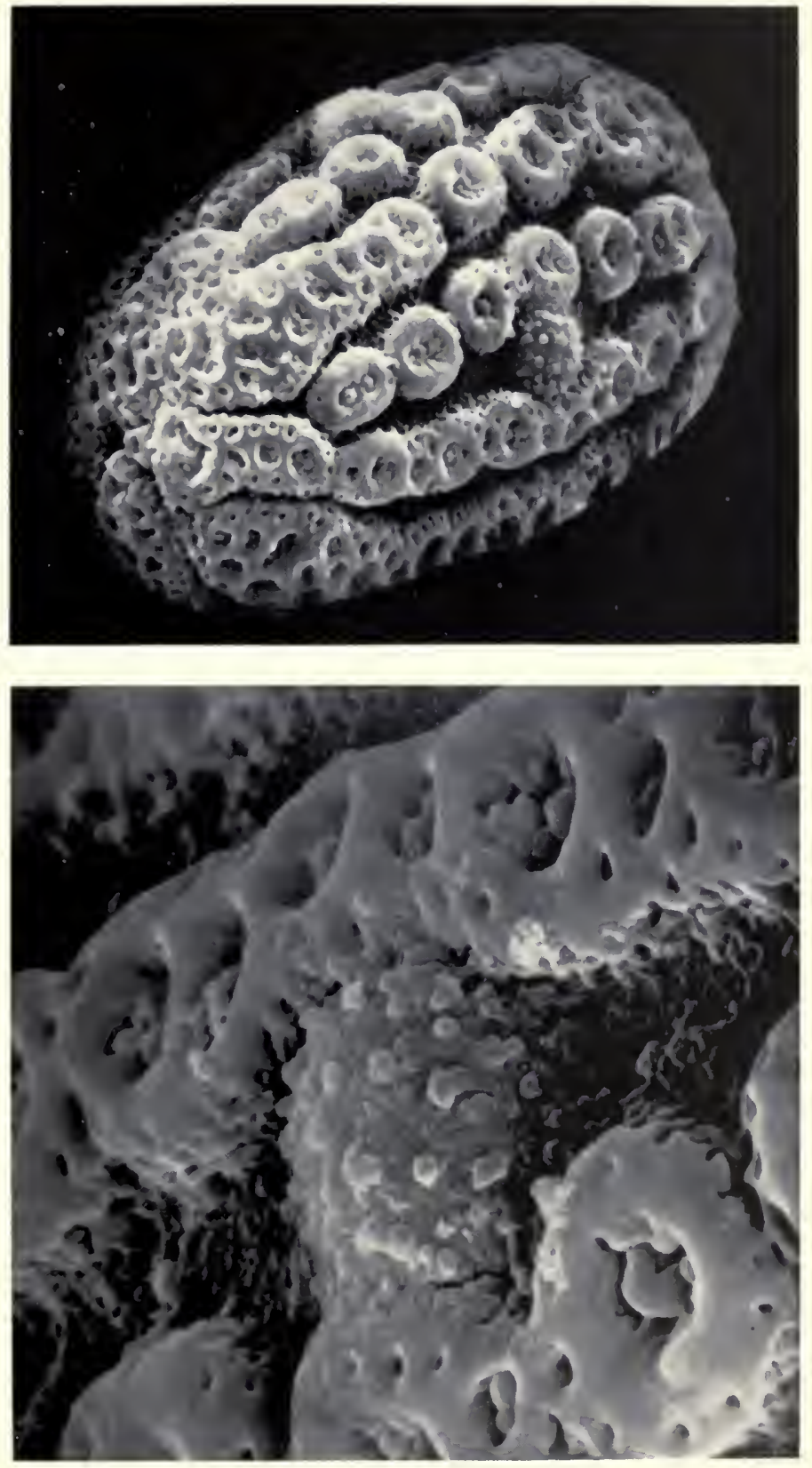

B

Fig. 9. Scanning electron microscope photographs of pollen grains of Justicia ensiflora: $\mathrm{A}, \times 990 ; \mathrm{B}, \times 4,950$. Photographs courtesy of the Department of Biological Sciences, University of Illinois at Chicago Circle. 


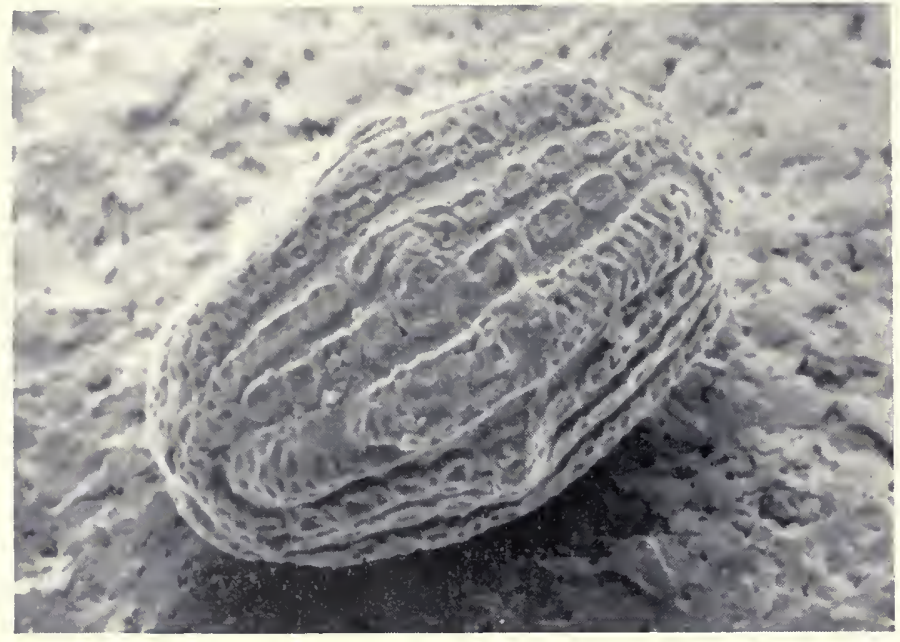

A

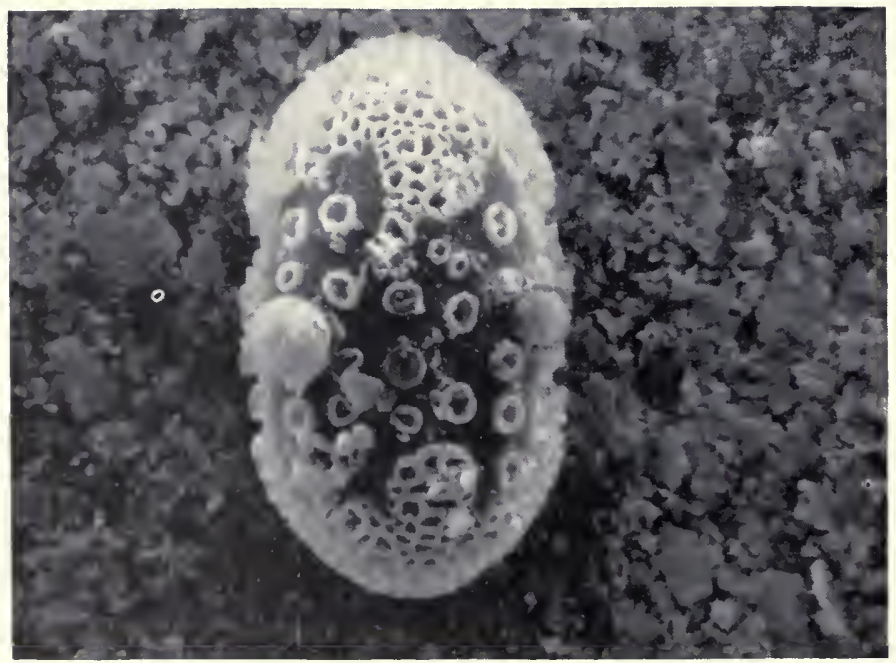

B

Fig. 10. Scanning electron microscope photographs of pollen grains of $\mathbf{A}$, Justicia montana, $\times 1,110 ; \mathrm{B}, J$ usticia silticola, $\times 1,000$. Photographs courtesy of the Department of Biological Sciences, University of Illinois at Chicago Circle. 


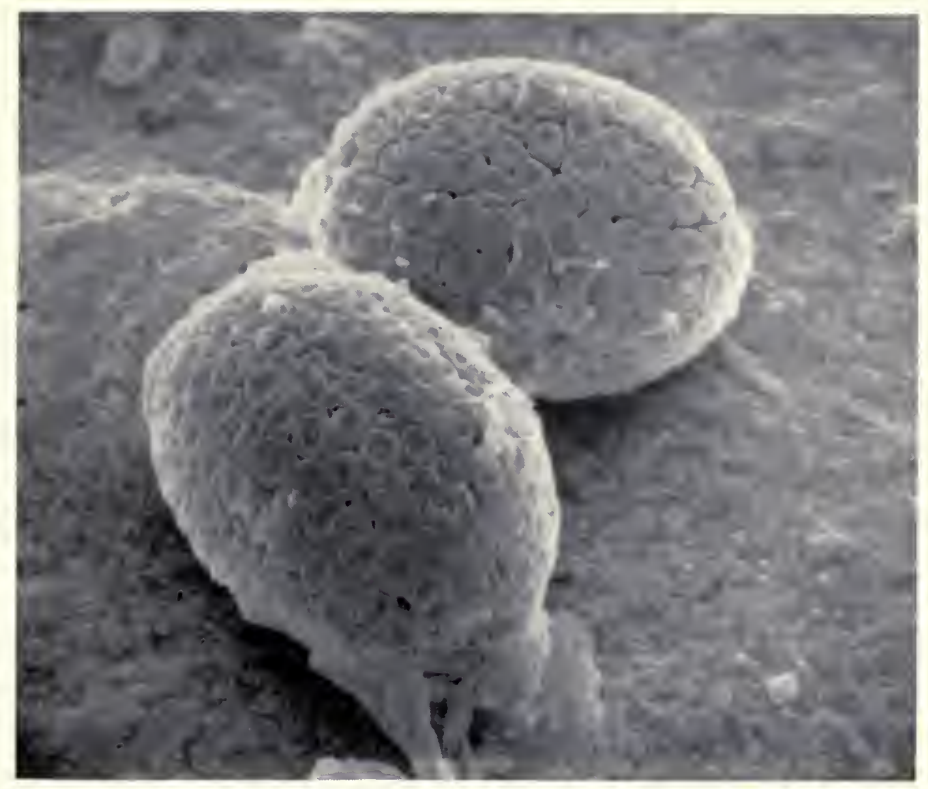

FIG. 11. Scanning electron microscope photograph of pollen grains of Poikilacanthus pansamalanus, $\times 890$. Photograph courtesy of the Department of Biological Sciences, University of Illinois at Chicago Circle. 



. 

(MN) 
UNIVERSITY OF ILLINOIS-URBANA

$580.5 F B$

FIELDIANA, BOTANYSCHICAGO

33-35



